\title{
Blastocyst-like structures generated solely from stem cells
}

Citation for published version (APA):

Rivron, N. C., Frias-Aldeguer, J., Vrij, E. J., Boisset, J-C., Korving, J., Vivie, J., Truckenmuller, R. K., van Oudenaarden, A., van Blitterswijk, C. A., \& Geijsen, N. (2018). Blastocyst-like structures generated solely from stem cells. Nature, 557(7703), 106-111. https://doi.org/10.1038/s41586-018-0051-0

Document status and date:

Published: 03/05/2018

DOI:

10.1038/s41586-018-0051-0

Document Version:

Publisher's PDF, also known as Version of record

Document license:

Taverne

Please check the document version of this publication:

- A submitted manuscript is the version of the article upon submission and before peer-review. There can be important differences between the submitted version and the official published version of record.

People interested in the research are advised to contact the author for the final version of the publication, or visit the DOI to the publisher's website.

- The final author version and the galley proof are versions of the publication after peer review.

- The final published version features the final layout of the paper including the volume, issue and page numbers.

Link to publication

\footnotetext{
General rights rights.

- You may freely distribute the URL identifying the publication in the public portal. please follow below link for the End User Agreement:

www.umlib.nl/taverne-license

Take down policy

If you believe that this document breaches copyright please contact us at:

repository@maastrichtuniversity.nl

providing details and we will investigate your claim.
}

Copyright and moral rights for the publications made accessible in the public portal are retained by the authors and/or other copyright owners and it is a condition of accessing publications that users recognise and abide by the legal requirements associated with these

- Users may download and print one copy of any publication from the public portal for the purpose of private study or research.

- You may not further distribute the material or use it for any profit-making activity or commercial gain

If the publication is distributed under the terms of Article $25 \mathrm{fa}$ of the Dutch Copyright Act, indicated by the "Taverne" license above, 


\section{Blastocyst-like structures generated solely from stem cells}

Nicolas C. Rivron ${ }^{1,2 *}$, Javier Frias-Aldeguer ${ }^{1,2}$, Erik J. Vrij ${ }^{1}$, Jean-Charles Boisset ${ }^{2}$, Jeroen Korving ${ }^{2}$, Judith Vivié2,3, Roman K. Truckenmüller ${ }^{1}$, Alexander van Oudenaarden ${ }^{2}$, Clemens A. van Blitterswijk ${ }^{1,5}$ \& Niels Geijsen ${ }^{2,4,5}$

The blastocyst (the early mammalian embryo) forms all embryonic and extra-embryonic tissues, including the placenta. It consists of a spherical thin-walled layer, known as the trophectoderm, that surrounds a fluid-filled cavity sheltering the embryonic cells ${ }^{1}$. From mouse blastocysts, it is possible to derive both trophoblast $^{2}$ and embryonic stem-cell lines ${ }^{3}$, which are in vitro analogues of the trophectoderm and embryonic compartments, respectively. Here we report that trophoblast and embryonic stem cells cooperate in vitro to form structures that morphologically and transcriptionally resemble embryonic day 3.5 blastocysts, termed blastoids. Like blastocysts, blastoids form from inductive signals that originate from the inner embryonic cells and drive the development of the outer trophectoderm. The nature and function of these signals have been largely unexplored. Genetically and physically uncoupling the embryonic and trophectoderm compartments, along with single-cell transcriptomics, reveals the extensive inventory of embryonic inductions. We specifically show that the embryonic cells maintain trophoblast proliferation and self-renewal, while fine-tuning trophoblast epithelial morphogenesis in part via a BMP4/Nodal-KLF6 axis. Although blastoids do not support the development of bona fide embryos, we demonstrate that embryonic inductions are crucial to form a trophectoderm state that robustly implants and triggers decidualization in utero. Thus, at this stage, the nascent embryo fuels trophectoderm development and implantation.

Although stem cells mimic development ${ }^{4-6}$, a stem cell-based model of the blastocyst is lacking. To address this, we confined cultured embryonic stem (ES) cells to an average of five cells per microwell ${ }^{7,8}$ (Extended Data Fig. 1a). These formed non-adherent aggregates within $24 \mathrm{~h}$, over which we laid trophoblast stem (TS) cells (Fig. 1a). Upon aggregation, the ES cells induced the formation of trophoblast cysts $(65 \mathrm{~h})$. At low frequency (less than $0.3 \%$ ), cells spontaneously organized into regular TS cell cysts with internal ES cell aggregates, which we termed blastoids (Extended Data Fig. 1b).

We optimized the organization by increasing the engulfment of ES and TS cells (Extended Data Fig. 1c, d), and analysed the functions of the WNT and cAMP signalling pathways, which correlate with the formation of the blastocoel fluid-filled cavity ${ }^{9,10}$. Indeed, blastocysts exposed to inhibitors of tankyrase or protein kinase A (PKA), which are used as antagonists of WNT and cAMP signalling, respectively, developed a smaller blastocoel (Extended Data Fig. 1e). Consistently, the trophectoderm cells ${ }^{10}$ and TS cells produce WNT family members 6 (Wnt6) and $7 \mathrm{~b}(W n t 7 b)$, and autocrine WNT activity (Extended Data Fig. 1f, g). cAMP and WNT pathway stimulation increased TS cell cavitation and blastoid formation using several ES and TS cell lines (Fig. 1b, Extended Data Fig. 1h, i). Blastoids formed efficiently at specific ratios (70\% when 8 ES cells and 20 TS cells are combined; Fig. 1c), expanded and stabilized within $65 \mathrm{~h}$ after seeding to diameters similar to E3.5 blastocysts ( $90 \mu \mathrm{m}$; Fig. 1d-f and Extended Data Fig. 1j).
We next analysed blastocyst transcription factors. Although the expression of pluripotency markers OCT4 (also known as POU5F1) and $\mathrm{NANOG}^{1}$ were maintained in the pluripotent compartment (Fig. 2a, b), mRNA expression of the trophoblast marker $C d x 2^{11,12}$ was low in both TS cells and blastoids compared to blastocysts (Extended Data Fig. 2a, b). The addition of the TS cell regulators FGF4 and TGF $\beta 1^{13}$ increased CDX2 expression in blastoids, but levels remained low (Extended Data Fig. 2b), prompting us to seek new regulators. On the basis of observations of the STAT pathway members in blastocysts (Extended Data Fig. 2c-g), we found that IL-11 (the most abundantly expressed ligand) or $8 \mathrm{Br}$-cAMP increased CDX2 protein levels ${ }^{12,13}$, complemented FGF4 and TGF $\beta 1$, maintained trophectoderm markers, and enhanced CDX2 expression in blastoids (Extended Data Figs. 2b, 3a-e and Fig. 2c). Blastoids remained permissive to the formation of primitive endoderm-like cells, albeit at lower numbers than blastocysts ${ }^{14}$ (Fig. 2d, Extended Data Fig. 4a-c). Cell number in the blastoid compartments was reminiscent of a mid-stage blastocyst (Extended Data Fig. 4a-c).

After injection into a foster blastocyst, ES and TS cells contribute to embryo and placental development, respectively. We analysed whether ES or TS cell lines derived de novo from blastoids had similar competences. The efficiency of TS cells derivation was similar between blastoids and blastocysts ( $90 \%$ generate $\mathrm{CDX}^{+}$colonies at passage 2 , Extended Data Fig. 5a), whereas CDX2-low blastoids (see Methods) displayed lower derivation efficiency (35\%). After injection into blastocysts, these de novo TS and ES cells contributed to the formation of the extra-embryonic tissues (embryonic day (E) 6.5 and E11.5 embryos), and epiblast, respectively (Fig. 2e, Extended Data Fig. 5a). Thus, the blastoid environment maintains the developmental potential of both lineages.

Blastoids transferred into the uterus of pseudo-pregnant mice induced deciduae formation with typical local vascular permeability (Fig. 2f), suggesting anastomosis of trophoblasts with the mother's vascular system ${ }^{15}$. Indeed, blastoid trophoblasts generated cells incorporated into the ingrowing maternal vasculature and expressing proliferin, a marker for trophoblast giant cells ${ }^{6,16}$ (Fig. 2g). Blastoids did not support full bona fide embryonic development, but generated numerous cells positive for a variety of extra-embryonic markers of different post-implantation trophoblast cell types ${ }^{6,15,17}$ (Extended Data Fig. 5b). Decidualization is a complex process regulated by the hormonal cycle and endometrium and stimulated by the embryo in rodents ${ }^{18}$. It can be partly reproduced by intraluminal deposition of sesame oil (deciduoma). We thus analysed the specificity of the decidualization process. Injection of vehicle medium alone did not induce decidualization (Fig. $2 \mathrm{~h}$ and Extended Data Fig. 5c). Blastocysts and blastoids formed small, discrete deciduae, whereas oil triggered the formation of larger, more continuous deciduomata (Extended Data Fig. 5d). How the conceptus regulates decidualization is not well understood; however, Aldh $3 a 1$ is one of the rare genes induced in the

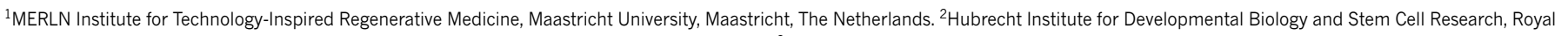

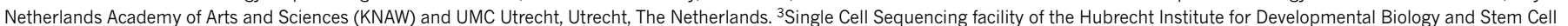
Research, Royal Netherlands Academy of Arts and Sciences (KNAW) and UMC Utrecht, Utrecht, The Netherlands. ${ }^{4}$ Department of Clinical Sciences of Companion Animals, Faculty of Veterinary Medicine, Utrecht University, Utrecht, The Netherlands. ${ }^{5}$ These authors contributed equally: Clemens A. van Blitterswijk, Niels Geijsen. *e-mail: n.rivron@hubrecht.eu 


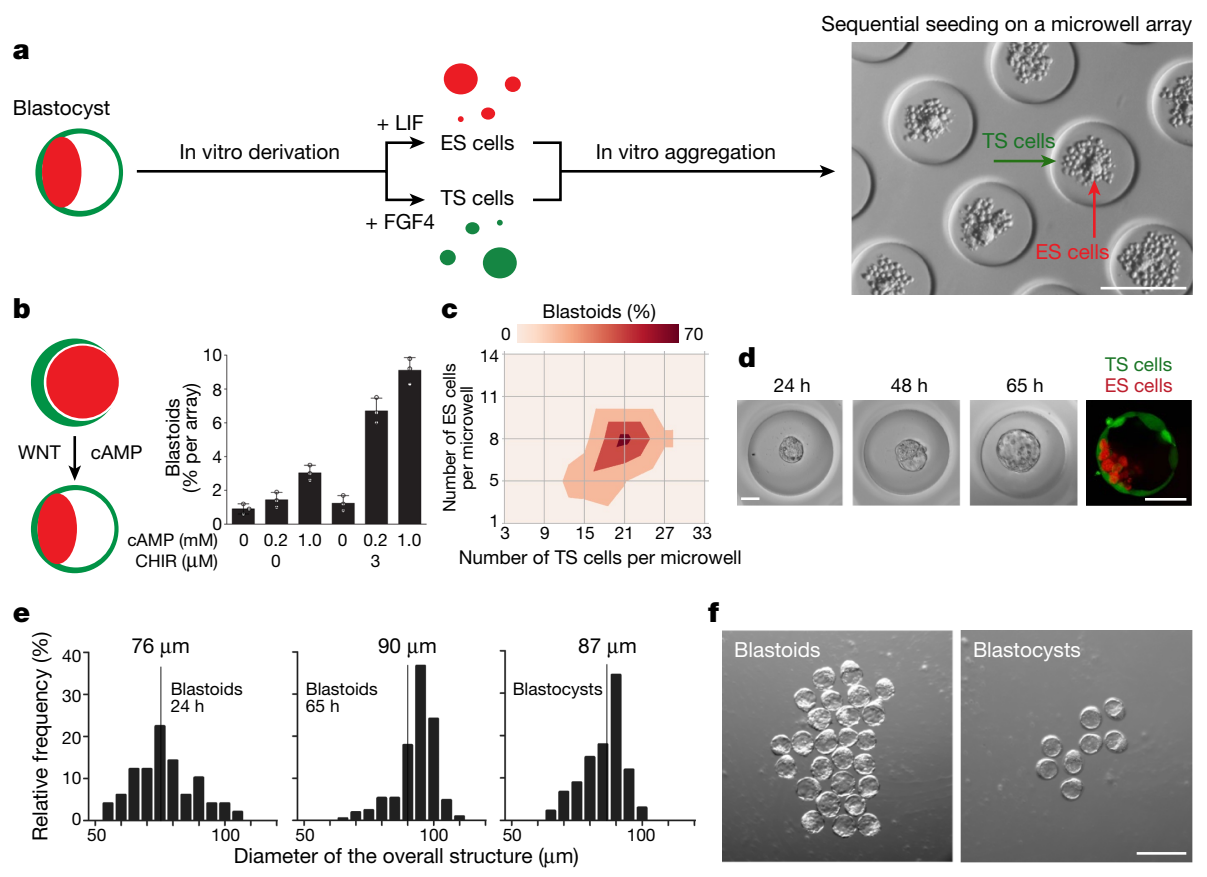

Fig. 1 | Embryonic and trophoblast stem cells form blastocyst-like structures in vitro. a, Schematic of blastoid formation. ES and TS cells are derived from blastocysts (left), then sequentially combined using a microwell array (right) ${ }^{7}$. ES cells are seeded to form non-adherent aggregates within $24 \mathrm{~h}$ (right, red arrow denotes a 24-h aggregate). TS cells are then added (right, green arrow denotes TS cells upon seeding). Scale bar, $200 \mu \mathrm{m}$. b, Aggregates of ES cells engulfed by TS cells were exposed to a WNT activator ( $3 \mu \mathrm{M}$ CHIR99021; CHIR) and a cAMP analogue $(0.2$ or $1 \mathrm{mM} 8 \mathrm{Br}$-cAMP; cAMP). Yields of blastoids are shown (measured as the percentage of microwells containing a TS cell cyst enclosing an ES cell, $65 \mathrm{~h}$ after TS cell addition). 8Br-cAMP plus CHIR99021 generated significantly higher yields of $9 \%$ blastoids ( $P=0.006$, two-sided Student's $t$-test). $n=3$ independent microwell arrays. Error bars are s.d. c, Blastoid

decidua by the implanting conceptus ${ }^{18}$. Consistently, ALDH3A1 was locally expressed in a group of decidual cells in the mesometrial side of blastocyst- and blastoid-induced deciduae (Fig. 2i and Extended Data Fig. 5e). Thus, the blastoid recapitulates key aspects of uterine
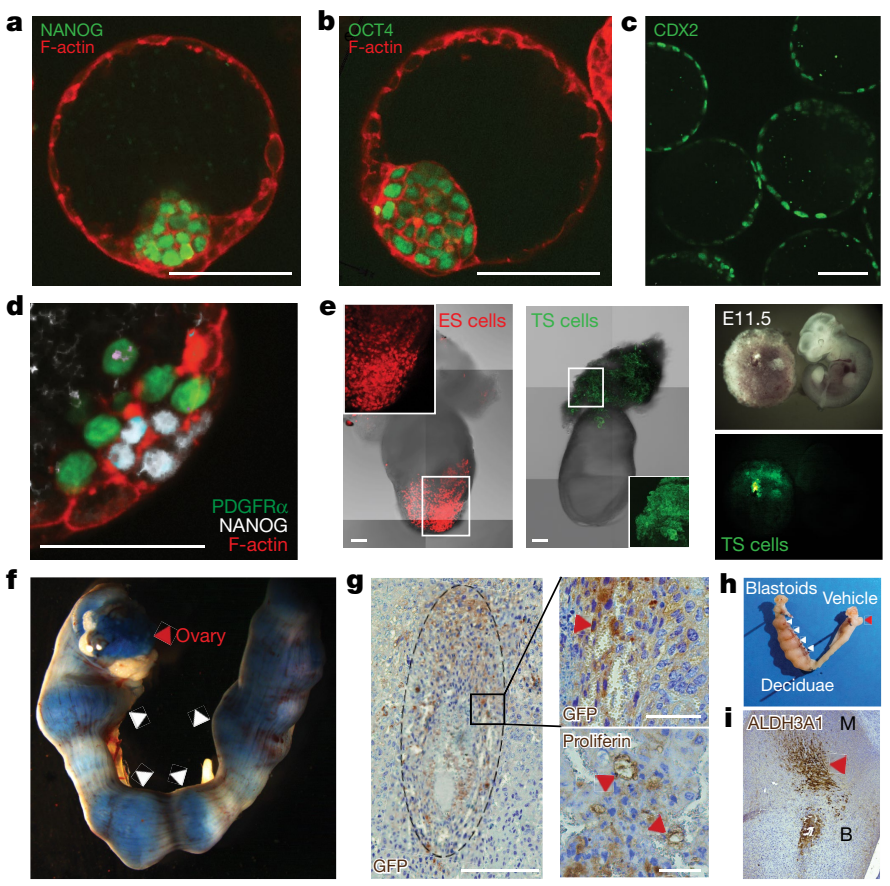

yield as a function of the initial number of TS and ES cells in individual microwells. 70\% of microwells seeded with an optimal number of ES and TS cells contain a blastoid. d, Left, evolution of blastoid morphology from 24 to $65 \mathrm{~h}$. Right, blastoids formed with ES cells positive for red fluorescent protein (RFP)-tagged histone $\mathrm{H} 2 \mathrm{~B}\left(\mathrm{H} 2 \mathrm{~B}-\mathrm{RFP}^{+}\right.$ES cells; red) and TS cells positive for green fluorescent protein (GFP) ( $\mathrm{GFP}^{+} \mathrm{TS}$ cells; green). Scale bars, $50 \mu \mathrm{m}$. e, Distribution of the overall diameters of blastoids, at 24 and $65 \mathrm{~h}$, and of blastocysts collected on day E3.5. Bar plots indicate the percentage frequency of specific diameters. $n=50$ independent blastoids or blastocysts. Vertical line denotes the median. f, Light microscopy image showing blastoids and E3.5 blastocysts (high magnification images shown in Extended Data Fig. 1j. Scale bar, $200 \mu \mathrm{m}$. All experiments were repeated at least three times with similar results.

implantation (discrete decidualization, vascular anastomosis, and patterned ALDH3A1 expression in the decidua).

Comparing transcriptomes using unsupervised clustering analysis (Fig. 3a) confirmed that blastoids resembled blastocysts at E3.5, when

Fig. 2 Blastoids implant in utero and trigger the formation of patterned deciduae. a, b, Immunofluorescent staining for NANOG (green, a) and OCT4 (green, b) in blastoids counterstained with F-actin (red). c, Immunofluorescent staining for CDX2 within blastoids (Extended Data Fig. 2b). d, Immunofluorescent staining for NANOG (white) in blastoids formed with ES cells comprising a primitive endodermspecific PDGFR $\alpha-\mathrm{H} 2 \mathrm{~B}-\mathrm{GFP}$ reporter (green) and counterstained with F-actin (red). Scale bars, $50 \mu \mathrm{m}$ (a-d). e, E6.5 and E11.5 embryos from blastocysts injected with de novo blastoid-derived ES cells (left) and TS cells (middle and right). Insets show the contribution of $\mathrm{H}_{2} \mathrm{~B}-\mathrm{RFP}^{+} \mathrm{ES}$ cells to the epiblast (left) and of GFP ${ }^{+}$TS cells to the extra-embryonic tissue (middle). Also see Extended Data Fig. 5a. f, Uterus transferred with blastoids at E3.3-E3.5 and explanted at E7.5. Mice are injected systemically with Evan blue dye, revealing typical local vascular permeability of the implantation sites (deciduae: white arrowheads; ovary: red arrowhead). g, Left, anti-GFP staining of a decidua containing an in utero developed blastoid formed with GFP ${ }^{+}$TS cells (E6.5). Scale bar, $1 \mathrm{~mm}$. Right, antiGFP staining (top; scale bar, $100 \mu \mathrm{m}$ ) and proliferin (bottom; scale bar, $50 \mu \mathrm{m})$ within histological sections of deciduae including vascular lumens (red arrowheads). h, Uterus transferred with blastoids (left horn) and vehicle medium (right) at E3.3-E3.5, and explanted at E6.5 (deciduae: white arrowheads; ovary: red arrowhead). i, Anti-ALDH3A1 staining of a representative decidua induced by a blastoid. B, blastoid implantation site; $\mathrm{M}$, mesometrial side. Red arrowhead denotes the decidua sub-population expressing ALDH3A1. All experiments were repeated at least three times with similar results. 


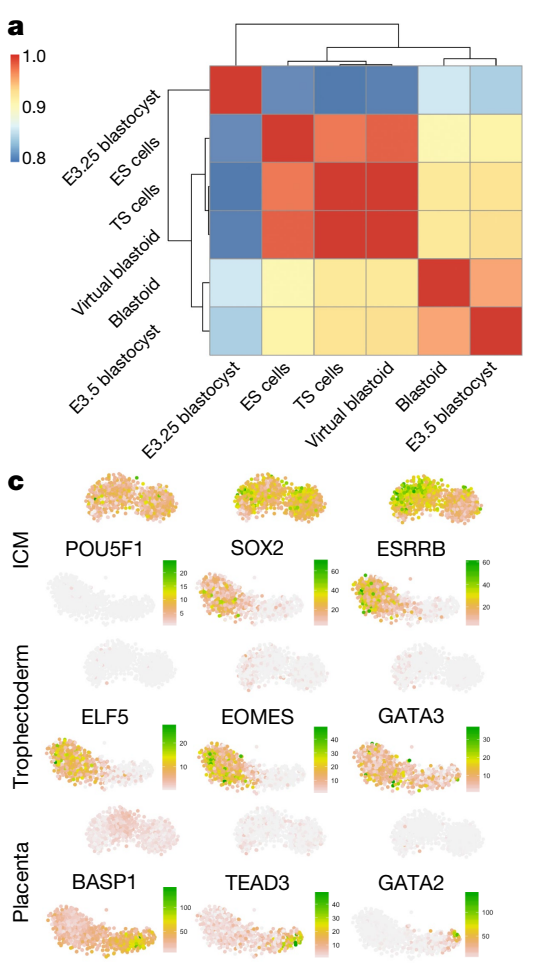

Fig. 3 | Communication between blastoid embryonic and trophoblast compartments shifts the transcriptome towards an E3.5 blastocyst state. a, Bulk sequencing. Whole-transcriptome distance map. The total number of either blastocysts or blastoids is 50 . $\mathbf{b}$-d, Single-cell RNA sequencing. $\mathbf{b}, t$-distributed stochastic neighbour embedding $(t$-SNE) map representation of transcriptome similarities between 1,577 cells collected from 2D-cultured parental ES cells in serum-free (2i) medium ( 316 cells) and parental TS cells in serum-free (TX) medium (290 cells), blastoid cells (367 cells), TS and ES cells cultured separately in blastoid medium within microwells (that is, 336 trophosphere cells, and 268 embryoid body cells). Arrows indicate transcriptome shifts due either to the culture environment (for example, culture medium and microwell confinement) or to the blastoid environment (for example, ES and TS cell communication and confinement within the blastoid cyst). Clustering is
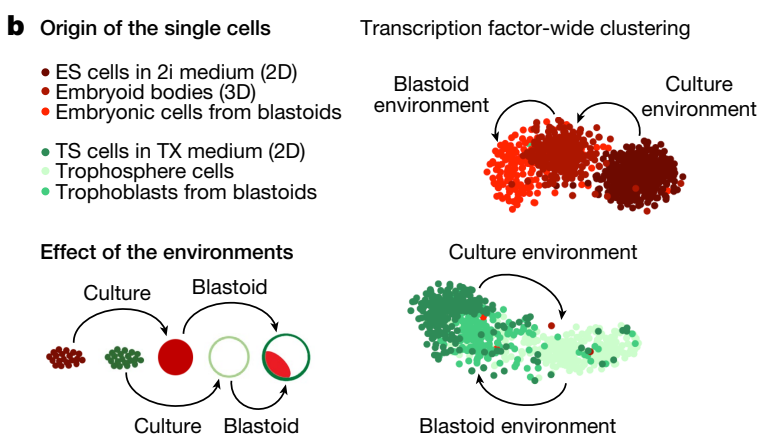

d

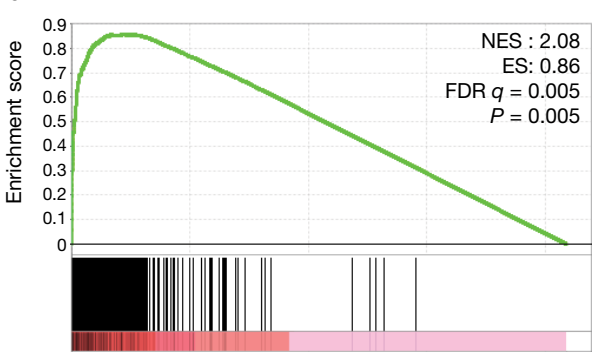

Gene set: genes enriched in blastocyst trophoblasts vs TS cells based on the transcription factors expressed in the blastocyst. See whole-transcriptome clustering in Extended Data Fig. 6c, d. The embryonic or trophoblast blastoid cells are identified based on FACS-sorting indexes. c, $t$-SNE map representation of key transcription factors for the ICM, trophectoderm and placenta. d, Comparison of trophoblasts from blastoids and blastocysts. Gene set enrichment analysis. Genes are ranked according to their difference in expression between trophoblasts of blastoids (left of the horizontal axis) and parental TS cells (right of the horizontal axis). Black bars depict the position of a gene set of 281 genes significantly enriched in trophoblasts of blastocyst compared to parental TS cells $(P=0.05$, see Supplementary Table 1 sheet 5$)$. This gene set is significantly enriched in the trophoblasts of blastoids (normalized enrichment score $(\mathrm{NES})=2.08, P=0.005$ ). ES, enrichment score; FDR, false discovery rate. lineage transcriptomes are stabilized ${ }^{19}$, consistent with the committed state of TS and ES cells. Similar clustering occurred when limited to transcription factors, and dissimilarities were primarily related to metabolism (Extended Data Fig. 6a, b and Supplementary Table 1 sheet 1). Importantly, the transcriptome of blastoids distinctly separated from their parental ES and TS cell lines (Fig. 3a). We then combined in silico the transcriptome of TS and ES cells cultured separately in blastoid medium: this virtual blastoid clustered with the parental cell lines, not with the blastoids (Fig. 3a), suggesting that the communication between the embryonic and trophoblast cells contributed to the E3.5like transcriptome shift. Comparison with the blastoid transcriptome identified differences within cell cycle, epithelial junctions and MAPK signalling pathways (Extended Data Fig. 6b, Supplementary Table 1 sheet 2), which all drive blastocyst formation ${ }^{2,20-22}$. A role for the TGF $\beta$ signalling pathway also surfaced, the contribution of which to blastocyst formation is less clear ${ }^{23,24}$.

We further evaluated the relative contribution of the culture condition (for example, culture medium, microwell confinement) and blastoid environment (for example, ES and TS cell communication, blastoid cyst confinement) to the transcriptome shift via single-cell sequencing of 2D-cultured parental TS and ES cells, blastoid cells, and TS and ES cells cultured individually in blastoid culture environment. In such conditions, TS cells alone formed trophospheres and ES cells formed embryoid bodies. Non-supervised clustering analysis clearly assessed the separation of embryonic cells (ES cells, blastoid embryonic cells and embryoid body cells) and trophoblast cells
(TS cells, blastoid trophoblast cells and trophosphere cells) (Fig. 3b and Extended Data Fig. 6c-e). Within the embryonic or trophoblast cluster, cells changed mainly owing to the culture environment (for example, culture medium and microwell confinement) and to the blastoid environment (for example, communication between embryonic and trophoblast cells, and cyst confinement). All embryonic cells maintained core pluripotency markers and did not express epiblast stem-cell markers (Fig. 3c and Extended Data Fig. 6g). Consistent with the de novo derivation of stem-cell lines, the core transcription factors of the TS cells were also maintained in the blastoid environment (Fig. 3c). In sharp contrast, the absence of embryonic cells strongly decreased these transcription factors in the cells of trophospheres, which expressed differentiation genes typical of post-implantation placental cell types (Fig. 3c and Extended Data Fig. 6f, g).

Consistent with the morphogenesis of a cyst, blastoid trophoblasts enriched in epithelial transcripts (Extended Data Fig. 6f, g and Supplementary Table 1 sheets 4-6), the proteins of which were correctly localized (Extended Data Fig. 7a-d). Finally, gene set enrichment analysis revealed that blastoid trophoblasts were largely enriched in the transcripts of blastocyst trophoblasts (Fig. 3d, Supplementary Table 1 sheet 5). Thus, the blastoid environment prevents the differentiation of trophoblasts, while fuelling the epithelial morphogenesis of a trophectoderm-like cyst.

To analyse functionally the embryonic inductions regulating trophectoderm development, we tested the specificity of the compartments' interactions by substituting the ES cells for other cell types, 
a

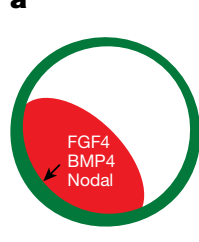

d

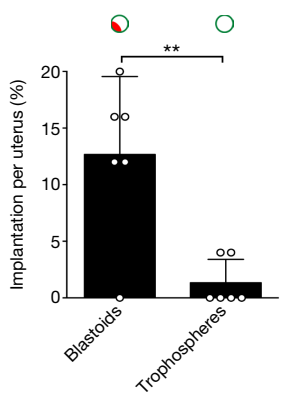

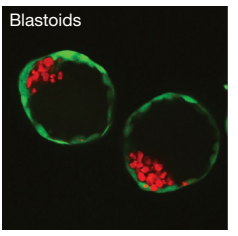

e

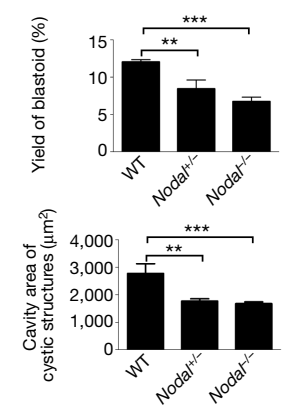

Fig. 4 | Embryonic inductions regulate trophectoderm proliferation, self-renewal, epithelial morphogenesis and implantation, partially via BMP4 and Nodal. a, Blastoids formed with GFP ${ }^{+}$TS cells and $\mathrm{H} 2 \mathrm{~B}-\mathrm{RFP}^{+} \mathrm{ES}$ cells are compared with trophospheres formed with $\mathrm{GFP}^{+} \mathrm{TS}$ cells alone. Scale bar, $100 \mu \mathrm{m}$. Images are representative of three experiments. b, c, Quantification of embryonic inductions previously assessed in blastocysts. The schemes above the graphics depict blastoids or trophospheres. b. Trophoblast proliferation. Count for the initial number of TS cells seeded (see Extended Data Fig. 1a) and present after $65 \mathrm{~h}$ within blastoids (B) and trophospheres (T). Horizontal bars indicate the mean number of trophoblasts. $* * * * P=2.10^{-5}$, two-sided Student's $t$-test. $n=30$ blastoids or trophospheres. Error bars indicate s.d. See Extended Data Fig. 10b. c, Trophoblast self-renewal. Colony formation unit (CFU) determined as the number of $\mathrm{CDX} 2^{+}$colonies divided by the mean number of trophoblasts in blastoids or trophospheres. Horizontal bars denote mean CFU. $* * * * P=4 \cdot 10^{-5}$, two-sided Student's $t$-test.

including mouse epiblast stem cells (EpiSCs, in vitro analogues of E5.75 embryos). EpiSCs induced the formation of fewer blastoids (fivefold) of smaller size (Extended Data Fig. 8a). Other cell types did not support trophectoderm development, demonstrating that specific inductions emerge from ES cells. FGF4, originating from the inner cell mass (ICM), regulates trophoblast proliferation and selfrenewal ${ }^{2,25,26}$. Consistently, ES cells expressed eightfold more Fgf4 mRNA than EpiSCs (Extended Data Fig. 8b), and induced transcriptional signatures for MAPK signalling activity and an enhanced cell cycle in blastoid trophoblasts (Extended Data Fig. 8c, d and Supplementary Table 1 sheet 7). Accordingly, there were twice as many trophoblasts in blastoids than trophospheres, and blastoid trophoblasts formed more (fivefold) $\mathrm{CDX} 2^{+}$colonies than trophosphere trophoblasts (Fig. 4b, c). We then tested whether morphogenesis of the epithelial cyst, an important transformation within blastoids, is functionally regulated by resident ES cells. Consistent with induction of trophectoderm morphogenesis genes, ES cell titration within blastoids increased both blastoid cavitation and diameter (Extended Data Fig. 8e, f). Finally, as the trophoblast state regulates the decidualization response ${ }^{16,18}$, we transferred blastoids and trophospheres in utero. Consistent with their post-implantation transcriptome signature, trophospheres had diminished potential for decidualization as compared to blastoids (sixfold, Fig. 4d). Thus, resident embryonic cells functionally maintain trophoblast proliferation and self-renewal, and prevent trophoblast differentiation into post-implantation placental cell types, while shaping their epithelial architecture and implantation potential.

The TGF $\beta$ signalling pathway is active in the blastocyst ${ }^{23,24}$. However, its functions are unknown owing to delayed detection of the defects
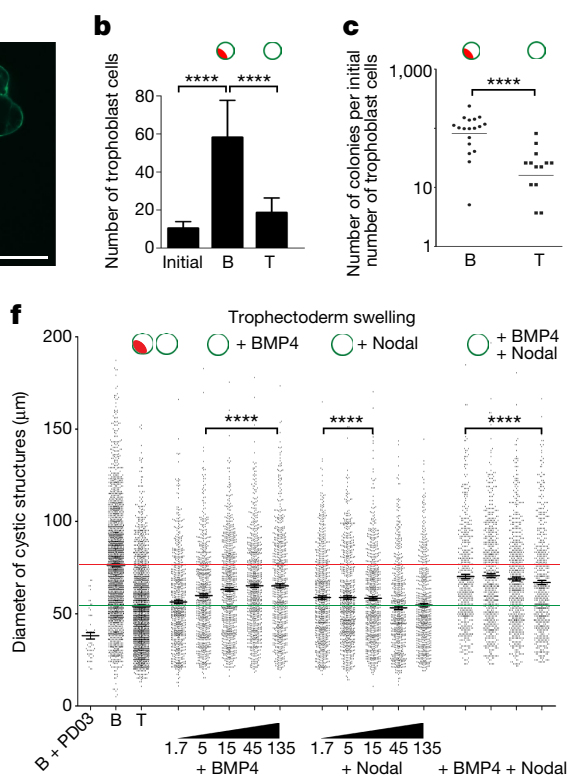

$n=13$ independent blastoids or trophospheres. Error bars indicate s.d. d, Trophectoderm implantation. Percentage of implantation sites in uteri transferred with blastoids or trophospheres at E3.3-E3.5, and explanted at E7.5. $n=6$ independent mice. Horizontal bars indicate mean percentage. $* * P=0.003$, Student's two-sided $t$-test. Error bars indicate s.d. e, f, Morphogenetic functions of TGF $\beta$ activators. e, Yield (top) and cavity area (bottom) of blastoids formed with wild-type (WT), Nodal ${ }^{+/-}$ and $\mathrm{Nodal}^{-1-}$ ES cells. Horizontal bars denote mean yield or cavity area. $* * * P=2 \cdot 10^{-4}$, two-sided Student's $t$-test. $n=3$ independent microwell arrays. Error bars indicate s.d. f, Overall diameter of blastoids, trophospheres and trophospheres exposed to BMP4, Nodal or their combination. Horizontal bars indicate mean of $n=250$ independent structures. Error bars denote s.e.m. Combinations of BMP4 and Nodal are (in order): $5 \mathrm{ng} \mathrm{ml}^{-1} \mathrm{BMP} 4+5 \mathrm{ng} \mathrm{ml}^{-1}$ Nodal; $45 \mathrm{ng} \mathrm{ml}^{-1}$ $\mathrm{BMP}+45 \mathrm{ng} \mathrm{ml}^{-1}$ Nodal; $45 \mathrm{ng} \mathrm{ml}^{-1} \mathrm{BMP} 4+5 \mathrm{ng} \mathrm{ml}^{-1}$ Nodal; $45 \mathrm{ng} \mathrm{ml}^{-1}$ BMP4 + $45 \mathrm{ng} \mathrm{ml}^{-1}$ Nodal.

after loss-of-function mutations (E5.5-E6.5) ${ }^{23}$. This delay may reflect a developmental robustness rooted in functional redundancy of ligands (for example, Nodal-activin-BMP), plasticity of signalling pathways, and/or technical limitations of detection ${ }^{23}$. Also, the temporal overlap of lineage commitment and morphogenesis in early blastocysts limits the interpretation of compartment-specific inducible genetic models. The blastoid system overcomes these limitations by permitting (i) genetic and physical uncoupling of the trophoblast and embryonic compartments, and (ii) disentangling blastocyst morphogenetic processes from earlier lineage commitment events.

In the blastoid, the embryonic cells induced TGF $\beta$ signalling pathway activity in trophoblasts (Extended Data Fig. 8c, d and Supplementary Table 1 sheets 6,7$)$. Also, the RNAs of the TGF $\beta$ activators Bmp4 and Nodal are largely restricted to the embryonic cells (Extended Data Fig. 9a). We concluded that BMP4 and Nodal produced by the embryonic compartment induce TGF $\beta$ activity in the trophectoderm.

To assess loss-of-function in the context of other inductions (for example, FGF4), we generated ES cells with a heterozygote or homozygote Nodal knockout (Extended Data Fig. 8b). These cells had a decreased capacity to form blastoids, which had smaller cavities (Fig. 4e). Next, we explored TGF $\beta$ gain-of-function activators. Stimulation of trophospheres with BMP4 and Nodal regulated a similar number of genes ( $30 \%$ overlap). Combined, they upregulated expression of the transcription factors $C d x 2, I d 2$ and $K l f 6$, induced WNT activity, which functionally regulates cavitation (see Supplementary Table 1 sheet 8 and Fig. 1b), and downregulated the expression of Cldn 4 and Krt8, which are overexpressed in differentiated trophospheres (Extended Data Fig. 9c-f, Supplementary Table 2 sheets $1-3)$. As for morphogenetic features, Nodal increased the cavitation 

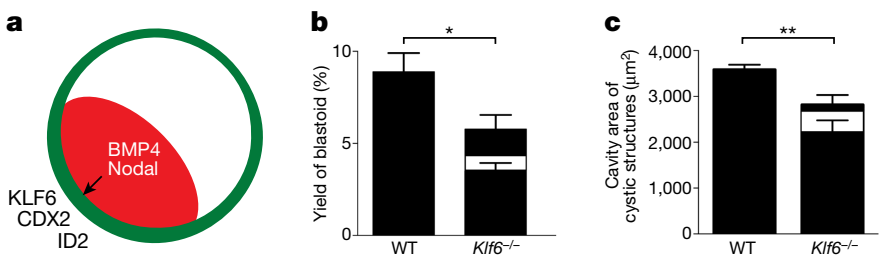

d

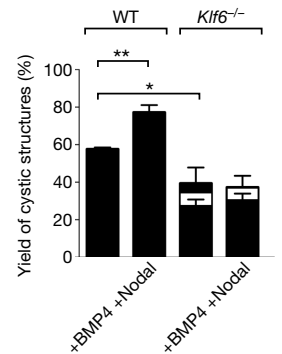

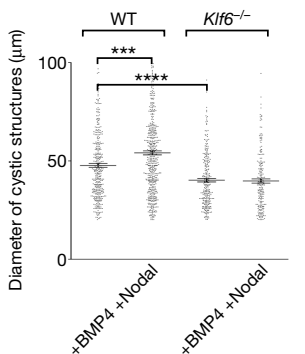

f

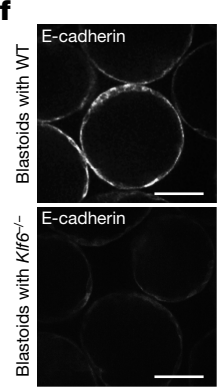

Fig. 5 | KLF6 mediates the response to BMP4 and Nodal, and trophoblast morphogenesis. a, Blastoid formation and stimulation of trophospheres with BMP4 and Nodal upregulates expression of KLF6, CDX2 and ID2 in trophoblasts. $\mathbf{b}$, Yield of blastoids formed with wild-type and $\mathrm{KlfG}^{-1-}$ TS cells (two clones). Horizontal bars indicate mean yield. $* P=0.01$, two-sided Student's $t$-test. $n=3$ independent microwell arrays. c, Cavity area of blastoids formed with wild-type and $\mathrm{Klf}^{-1-} \mathrm{TS}$ cells (two clones). Horizontal bars denote the mean cavity area. $* * P=0.005$, two-sided Student's $t$-test. $n=3$ independent microwell arrays. d, Yield of trophospheres formed with wild-type and $\mathrm{KlfG}^{-1-} \mathrm{TS}$ cells, and after stimulation with $45 \mathrm{ng} \mathrm{ml}^{-1} \mathrm{BMP} 4$ and $5 \mathrm{ng} \mathrm{ml}^{-1}$ Nodal. Horizontal bars indicate mean yield. $* P=0.02, * * P=0.001$, two-sided Student's $t$-test. $n=3$ independent microwell arrays. Error bars in $\mathbf{b}$-d denote s.d. e. Diameters of trophospheres formed with wild-type and $K l f 6^{-1-}$ TS cells, and after stimulation with $45 \mathrm{ng} \mathrm{ml}^{-1} \mathrm{BMP} 4$ and $5 \mathrm{ng} \mathrm{ml}^{-1}$ Nodal. Horizontal bars indicate mean diameter. $* * * P=0.001, * * * * P=0.0001$, two-sided Student's $t$-test. $n=80$. Error bars are s.e.m. f, Immunostaining for E-cadherin (DECMA antibody) in blastoids formed with wild-type and $K l f 6^{-1-}$ TS cells. Images are representative of three independent experiments. Scale bars, $50 \mu \mathrm{m}$.

of trophospheres and had a milder effect on their diameter, whereas BMP4 induced the opposite effect. BMP4 and Nodal together increased both the cavitation (Extended Data Figs. 9g, 10a) and diameter (120\%, Fig. 4f) of trophospheres. As there was no change in cell numbers (Extended Data Fig. 10b), we concluded that BMP4 and Nodal regulate cavitation and swelling, consistent with the regulation of epithelial components. Accordingly, TGF $\beta$ signalling pathway inhibition using LDN193189 reduced the size of the blastocoel cavity in blastocysts (Extended Data Fig. 10c). Thus, BMP4 and Nodal contribute to trophoblast epithelial morphogenesis.

Blastoid formation and the stimulation of trophospheres with BMP4 and Nodal both upregulated Klf6 in trophoblasts (Fig. 5a, Supplementary Table 2 sheets 1-3). Consistent with a continuum reflecting trophectoderm and placenta development, trophospheres strongly expressed Klf6, which is somehow involved in early placenta development ${ }^{27}$ (Extended Data Fig. 6g). We thus generated two $\mathrm{Klf6}^{-1-}$ TS cells lines (Extended Data Fig. 10d) and analysed trophoblast morphogenesis. In 2D culture, the lines appeared similar to the parental line (morphology, proliferation, and levels of E-cadherin; Extended Data Fig. 10e). However, mirroring the ES cell Nodal knockout phenotype, both TS cell lines had a reduced capacity to form blastoids, which had a smaller cavities (Fig. 5b, c). This defect was partly TS cell autonomous, as their capacity to form trophospheres was also reduced (Fig. 5d, e). In addition, contrary to their parental line, $\mathrm{Klf6}^{-1-}$ trophospheres did not respond to TGF $\beta$ activators (Fig. 5d, e, Extended Data Fig. 10f). KLF6 has been linked to epithelial functions and E-cadherin expression ${ }^{28}$. Indeed, E-cadherin and $K r t 8$ were downregulated within $K l f 6^{-l-}$ blastoids (Fig. 5f, Extended Data Fig. 10g). Thus, Klf6 is an important target of BMP4 and Nodal, regulating the epithelial morphogenesis of the trophectoderm.

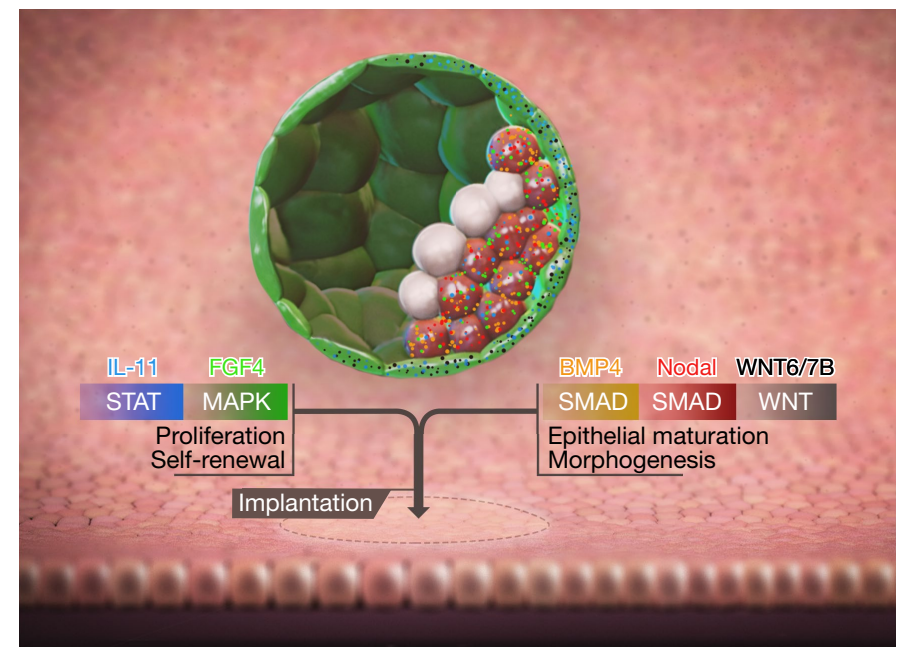

Fig. 6 | Embryonic inductions drive trophectoderm development and implantation. Left, trophectoderm proliferation and self-renewal. FGF4 largely originates from the embryonic compartment. IL-11 is the most abundantly expressed STAT regulator, and originates from both the embryonic and trophectoderm compartments. Together, FGF4 and IL-11 regulate trophoblast proliferation and self-renewal, and CDX2 expression. Right, trophectoderm epithelial maturation and morphogenesis. BMP4 and Nodal largely originate from the embryonic compartment and, besides maintaining the trophoblast stem-cell state ${ }^{13}$, regulate trophectoderm epithelial maturation and morphogenesis. Among WNT ligands ${ }^{10}$, WNT6 and WNT7B are expressed in the trophectoderm, and regulate epithelial morphogenesis. Altogether, signals originating from the embryonic cells fuel trophoblast proliferation, morphogenesis and generate a trophoblast state prone to in utero implantation.

Assigning functional roles to compartment interactions in blastocysts is challenging owing to (i) the difficulty to form blastocysts without ICM cells (trophospheres) ${ }^{26,29}$, (ii) the temporal overlap between lineage commitment and blastocyst morphogenesis, and (iii) the relative speed of blastocyst development, which limits the interpretation of compartment-specific inducible models. Here, we describe the formation of blastoids, which morphologically and transcriptionally resemble E3.5 blastocysts, recapitulate key features of trophectoderm development, and implant in utero. This model overcomes many limitations of blastocyst research and proposes new mechanisms of embryonic inductions that drive trophectoderm development and in utero implantation (Fig. 6).

\section{Online content}

Any Methods, including any statements of data availability and Nature Research reporting summaries, along with any additional references and Source Data files, are available in the online version of the paper at https://doi.org/10.1038/s41586018-0051-0.

Received: 21 September 2015; Accepted: 28 February 2018; Published online 2 May 2018.

1. Wennekamp, S., Mesecke, S., Nédélec, F. \& Hiiragi, T. A self-organization framework for symmetry breaking in the mammalian embryo. Nat. Rev. Mol. Cell Biol. 14, 452-459 (2013).

2. Tanaka, S., Kunath, T., Hadjantonakis, A. K., Nagy, A. \& Rossant, J. Promotion of trophoblast stem cell proliferation by FGF4. Science 282, 2072-2075 (1998).

3. Ying, Q.-L. et al. The ground state of embryonic stem cell self-renewal. Nature 453, 519-523 (2008).

4. van den Brink, S. C. et al. Symmetry breaking, germ layer specification and axial organisation in aggregates of mouse embryonic stem cells. Development $\mathbf{1 4 1}$ 4231-4242 (2014).

5. Harrison, S. E., Sozen, B., Christodoulou, N., Kyprianou, C. \& Zernicka-Goetz, M. Assembly of embryonic and extraembryonic stem cells to mimic embryogenesis in vitro. Science 356, eaal1810 (2017).

6. Rai, A. \& Cross, J. C. Three-dimensional cultures of trophoblast stem cells autonomously develop vascular-like spaces lined by trophoblast giant cells. Dev. Biol. 398, 110-119 (2015). 
7. Rivron, N. C. et al. Tissue deformation spatially modulates VEGF signaling and angiogenesis. Proc. Natl Acad. Sci. USA 109, 6886-6891 (2012).

8. Vrij, E. et al. Directed assembly and development of material-free tissues with complex architectures. Adv. Mater. 28, 4032-4039 (2016).

9. Manejwala, F., Kaji, E. \& Schultz, R. M. Development of activatable adenylate cyclase in the preimplantation mouse embryo and a role for cyclic AMP in blastocoel formation. Cell 46, 95-103 (1986).

10. Kemp, C., Willems, E., Abdo, S., Lambiv, L. \& Leyns, L. Expression of all Wnt genes and their secreted antagonists during mouse blastocyst and postimplantation development. Dev. Dyn. 233, 1064-1075 (2005).

11. Ralston, A. \& Rossant, J. Cdx2 acts downstream of cell polarization to cell-autonomously promote trophectoderm fate in the early mouse embryo. Dev. Biol. 313, 614-629 (2008).

12. McDole, K. \& Zheng, Y. Generation and live imaging of an endogenous $\mathrm{Cdx} 2$ reporter mouse line. Genesis 50, 775-782 (2012).

13. Kubaczka, C. et al. Derivation and maintenance of murine trophoblast stem cells under defined conditions. Stem Cell Reports 2, 232-242 (2014)

14. Plusa, B., Piliszek, A., Frankenberg, S., Artus, J. \& Hadjantonakis, A.-K. Distinct sequential cell behaviours direct primitive endoderm formation in the mouse blastocyst. Development 135, 3081-3091 (2008).

15. Simmons, D. G., Fortier, A. L. \& Cross, J. C. Diverse subtypes and developmental origins of trophoblast giant cells in the mouse placenta. Dev. Biol. 304, 567-578 (2007).

16. Red-Horse, K. et al. Trophoblast differentiation during embryo implantation and formation of the maternal-fetal interface. J. Clin. Invest. 114, 744-754 (2004).

17. Latos, P. A. \& Hemberger, M. From the stem of the placental tree: trophoblast stem cells and their progeny. Development 143, 3650-3660 (2016).

18. McConaha, M. E., Eckstrum, K., An, J., Steinle, J. J. \& Bany, B. M. Microarray assessment of the influence of the conceptus on gene expression in the mouse uterus during decidualization. Reproduction 141, 511-527 (2011)

19. Ohnishi, Y. et al. Cell-to-cell expression variability followed by signal reinforcement progressively segregates early mouse lineages. Nat. Cell Biol. 16 27-37 (2014)

20. Gotoh, N. et al. The docking protein FRS2alpha is an essential component of multiple fibroblast growth factor responses during early mouse development. Mol. Cell. Biol. 25, 4105-4116 (2005).

21. Saba-El-Leil, M. K. et al. An essential function of the mitogen-activated protein kinase Erk2 in mouse trophoblast development. EMBO Rep. 4, 964-968 (2003).

22. Arman, E., Haffner-Krausz, R., Chen, Y., Heath, J. K. \& Lonai, P. Targeted disruption of fibroblast growth factor (FGF) receptor 2 suggests a role for FGF signaling in pregastrulation mammalian development. Proc. Natl Acad. Sci. USA 95, 5082-5087 (1998).

23. Papanayotou, C. \& Collignon, J. Activin/Nodal signalling before implantation: setting the stage for embryo patterning. Phil. Trans. R. Soc. Lond. B 369, 1-8 (2014).

24. Mesnard, D. \& Constam, D. B. Imaging proprotein convertase activities and their regulation in the implanting mouse blastocyst. J. Cell Biol. 191, 129-139 (2010).
25. Gardner, R. L. Flow of cells from polar to mural trophectoderm is polarized in the mouse blastocyst. Hum. Reprod. 15, 694-701 (2000).

26. Gardner, R. L., Papaioannou, V. E. \& Barton, S. C. Origin of the ectoplacental cone and secondary giant cells in mouse blastocysts reconstituted from isolated trophoblast and inner cell mass. J. Embryol. Exp. Morphol. 30, 561-572 (1973).

27. Matsumoto, N. et al. Developmental regulation of yolk sac hematopoiesis by Kruppel-like factor 6. Blood 107, 1357-1365 (2006).

28. DiFeo, A. et al. E-cadherin is a novel transcriptional target of the KLF6 tumor suppressor. Oncogene 25, 6026-6031 (2006).

29. Tarkowski, A. K. \& Wróblewska, J. Development of blastomeres of mouse eggs isolated at the 4- and 8-cell stage. J. Embryol. Exp. Morphol. 18, 155-180 (1967).

Acknowledgements We would like to thank J. Deschamps for providing the Cdx2-eGFP mice; M. Creyghton for providing V6.5 mouse ES cells; V. Prideaux, J. Garner and J. Rossant for providing the $F_{4}$ mouse TS cell lines; A. $K$. Hadjantonakis for providing the PDGFR $\alpha$-H2B-GFP mouse ES cells; N. Schelling for helping with logistics; S. van der Elst for helping with FACS assays; A. de Graaf for helping with microscopes; L. Yvernogeau for helping with the imaging of embryos; B. El Haddouti for helping with uterus injections; $\mathrm{H}$. Begthel for helping with histology; W. de Lau for helping with the TCF luciferase assay; C. Rabouille and $\mathrm{H}$. Clevers for commenting on the manuscript. N.C.R. is grateful for support from The Netherlands Organisation for Scientific Research (NWOZonMw) Translational Adult Stem Cell grant (116005008). We apologize that all relevant publications could not be cited.

Author contributions N.C.R. conceived and directed the project, conducted the experiments and wrote the manuscript. J.F.-A. performed the single-molecule FISH assay, the GRT-PCR assay, contributed to generating the CRISPR knockout lines and to the RNA-sequencing assays. E.J.V. performed the high-content imaging assays. J.K. completed the blastocyst complementation assays and the in uteri transfers. J.V. helped prepare the libraries of single cells for RNA sequencing. J.-C.B. contributed to the RNA-sequencing assays. R.K.T. contributed to the design of the microwell array. A.v.O. contributed to the RNAsequencing assays. C.A.v.B and N.G. helped to direct the project and contributed equally to the study. All the authors discussed and corrected the manuscript.

Competing interests N.C.R., E.J.V., C.A.v.B. and N.G. are inventors on the patent US14/784,659 and PCT/NL2014/050239 (April 2014).

\section{Additional information}

Extended data is available for this paper at https://doi.org/10.1038/s41586018-0051-0.

Supplementary information is available for this paper at https://doi. org/10.1038/s41586-018-0051-0.

Reprints and permissions information is available at http://www.nature.com/ reprints.

Correspondence and requests for materials should be addressed to N.C.R. Publisher's note: Springer Nature remains neutral with regard to jurisdictional claims in published maps and institutional affiliations. 


\section{METHODS}

No statistical methods were used to predetermine sample size. The experiments were not randomized, and investigators were not blinded to allocation during experiments and outcome assessment.

Culture of ES cells. Experiments were done using the following cell lines: V6.5,

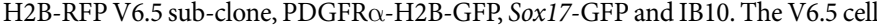
line was derived from $\mathrm{C} 57 \mathrm{BL} / 6 \times 129 / \mathrm{Sv}$ background and obtained from the laboratory of R. Jaenisch. The IB10 cell line was a subclone of the E14 cell line (129/Ola) and obtained from the laboratory of $\mathrm{H}$. Clevers. The PDGFR $\alpha-\mathrm{H} 2 \mathrm{~B}-\mathrm{GFP}$ cell line was derived from an ICR background and obtained from the laboratory of A.-K. Hadjantonakis. A Sox17-GFP cell line was derived from unknown background and obtained from the laboratory of S. Morrison. All cells were cultured in $2 \mathrm{i}$ conditions, meaning on gelatin-coated plates in B27N2 medium complemented with leukaemia inhibitory factor (LIF, $\left.10 \mathrm{ng} \mathrm{ml}^{-1}\right)$, PD0325901 ( $1 \mu \mathrm{M}$, AxonMed 1408) and CHIR99021 (3 $\mathrm{MM}$, AxonMed 1386) as developed previously ${ }^{3}$. Cells were routinely passaged every two days for 15 days before being used for blastoid formation. Culture of TS cells. Experiments were done using the $\mathrm{F}_{4}, \mathrm{~F}_{1}$ and $C d x 2$-eGFP cell lines. The TS cell lines $\mathrm{F}_{4}(\mathrm{ICR} \times \mathrm{ICR})$ were obtained from the laboratory of J. Rossant. The $\mathrm{F}_{1}(\mathrm{CBA} \times \mathrm{C} 57 \mathrm{BL} / 6)$ and $\mathrm{Cd} d x 2$-eGFP TS cell lines were derived by N. Rivron according to the methods described by previously ${ }^{2}$. Cdx2-eGFP TS cell lines were derived from a mouse reporter line in which eGFP is fused to the endogenous locus of $C d x 2$, as described previously ${ }^{12}$. Cells were then cultured on Matrigel in phenol red-free TX medium, a serum-free medium developed previously $^{13}$. TX medium contains DMEM/F12 (phenol red-free, with L-glutamin), L-ascorbic-acid-2-phosphate $\left(64 \mu \mathrm{g} \mathrm{ml}^{-1}\right)$, sodium selenite $\left(14 \mathrm{ng} \mathrm{ml}^{-1}\right)$, insulin $\left(19.4 \mu \mathrm{g} \mathrm{ml}^{-1}\right)$, sodium bicarbonate $\left(543 \mu \mathrm{g} \mathrm{ml}^{-1}\right)$, holo-transferin $\left(10.7 \mu \mathrm{g} \mathrm{ml}^{-1}\right)$, penicillin streptomycin, FGF4 $\left(25 \mathrm{ng} \mathrm{ml}^{-1}\right)$, TGF $\beta 1\left(2 \mathrm{ng} \mathrm{ml}^{-1}\right)$ and heparin $(1 \mu \mathrm{g}$ $\left.\mathrm{ml}^{-1}\right)$. Alternatively, and when mentioned, TS cells were cultured in serum-rich conditions (TS medium) as described previously ${ }^{2}$. Cells were routinely passaged every 4 days before being used for blastoid formation.

Culture of other cell types. Mouse EpiSCs were in cultured serum-free conditions, as previously described ${ }^{30}$. Human ES cells were cultured in E8 medium. C2C12 and COS7 cells were culture in DMEM (Gibco, phenol red-free with L-glutamine), supplemented with 10\% fetal bovine serum (FBS) (Sigma-Aldrich).

Microwell arrays. Microwell arrays were formed as previously described ${ }^{7,8}$ and inserted into 12-well plates or directly imprinted into 96-well plates. Each microwell array included 1,000 or 400 microwells, respectively, with a diameter of $200 \mu \mathrm{m}$, as described in Extended Data Fig. 1a.

Culture of blastoids. The full protocol was repeated independently in the Hubrecht and MERLN institutes, and is available at Protocol Exchange ${ }^{31}$ and on http://www.blastoid. org. ES cells were seeded by dispensing a cell suspension in DMEM medium (Gibco 31966021) with non-essential amino acids (Gibco, 11140-050), $\beta$-mercaptoethanol (Gibco, 21985-023), 10\% FBS (Sigma-Aldrich) and LIF $\left(10^{3} \mathrm{U} \mathrm{ml}^{-1}\right)$, on top of the microwell arrays with a cell concentration resulting in the pooling of a mean of five cells per microwell. Within $24-36 \mathrm{~h}$, the ES cells formed tight, round aggregates. TS cells were then seeded on top of the ES cells aggregates at a concentration resulting in the pooling of a mean of 12 cells per microwell. Upon settling of the cells within the microwells, TX medium was added and complemented with Y27632 $(20 \mu \mathrm{M}$, AxonMed 1683), CHIR99021 (3 $\mu \mathrm{M}$, AxonMed 1386), 8Br-cAMP (1 mM, Biolog Life Science Institute B007E), FGF4 (25 ng ml ${ }^{-1}, \mathrm{R} \& \mathrm{D}$ systems $\left.5846 \mathrm{~F} 4\right), \mathrm{TGF} 31$ (15ng $\mathrm{ml}^{-1}$, Peprotech 100-21), IL-11 (30 $\mathrm{ng} \mathrm{ml}^{-1}$, Peprotech 200-11) and heparin $\left(1 \mu \mathrm{g} \mathrm{ml}^{-1}\right)$. The time of TS cell seeding is considered as the starting point $(0 \mathrm{~h})$. Within $24 \mathrm{~h}$, the TS cells aggregated with the ES cells. At 24h, $1 \mathrm{mM} 8 \mathrm{Br}$-cAMP was added to the medium. Within $48 \mathrm{~h}, 2-8 \%$ of the aggregates formed a cavity, which expanded and stabilized by $65 \mathrm{~h}$. A blastoid is defined based on the morphological parameters of E3.5 blastocysts, as a cystic structure with an outer circularity superior to 0.9 (circularity $=4 \pi$ (area/ perimeter $\left.{ }^{2}\right)$ ), and a diameter comprised between 70 and $110 \mu \mathrm{m}$, including a single regular cavity lined by a single layer of TS cells and including ES cells. Cystic structures refers to all the TS-cell cavitated structures with a diameter of cavity greater than $20 \mu \mathrm{m}$. WNT3A-conditioned medium was obtained from the laboratory of $\mathrm{H}$. Clevers; WNT3A recombinant protein was obtained from Cell Guidance Systems. XAV939, a tankyrase inhibitor (Tocris Bioscience), is used as an antagonist of WNT signalling and acts via stimulation of $\beta$-catenin degradation and stabilization of axin; XAV939 was used at $15 \mu \mathrm{M}$.

Trophospheres were obtained by seeding TS cells (mean of 12 cells per microwell) in the same medium as used for blastoids. TX medium without growth factors (blank medium) refers to medium containing DMEM/F12 (phenol red-free, with L-glutamine), L-ascorbic-acid-2-phosphate $\left(64 \mu \mathrm{g} \mathrm{ml}^{-1}\right)$, sodium selenite $\left(14 \mathrm{ng} \mathrm{ml}^{-1}\right)$, insulin $\left(19.4 \mu \mathrm{g} \mathrm{ml}^{-1}\right)$, sodium bicarbonate $\left(543 \mu \mathrm{g} \mathrm{ml}^{-1}\right)$, holo-transferin $\left(10.7 \mu \mathrm{g} \mathrm{ml}^{-1}\right)$ and penicillin streptomycin.

TCF luciferase reporter assay. A TOP/TK-Renilla reporter plasmid system was used for the detection of $\beta$-catenin driven Wnt-transcriptional activity, as previously described ${ }^{32}$. The TOP reporter construct contains three optimal copies of $\mathrm{T}$ cell factor (TCF)/lymphoid enhancer factor (LEF) transcription factor sites upstream of a thymidine kinase minimal promoter that, when bound by $\beta$-catenin induces transcription of the luciferase reporter gene. The Renilla reporter construct contains thymidine kinase-Renilla luciferase (TK-Renilla), which drives strong WNT-independent activity of the Renilla gene and serves as a measure of cell viability. Luciferase reporter gene analysis was performed in TS cells cultured in 2D: 16,000 cells were seeded into each well of a 96-well plate in TX culture condition. After $24 \mathrm{~h}$, the cells were transiently co-transfected using Lipofectamine 3000 (Invitrogen, L3000001). Cells were stimulated 16h later with TX or blastoid culture medium and the Porcupin inhibitor IWP2 $(2.5 \mu \mathrm{M})$. TX without growth factors was used as a negative control and WNT3A-conditioned medium was used as a positive control. After $24 \mathrm{~h}$, cells were lysed using passive lysis buffer and luciferase and Renilla activity was measured with the Dual Luciferase Reporter Assay System (Promega, E1910). Each condition was performed in quadruplicate and the reporter activity was expressed as mean \pm s.d.

Screening for regulators of $\boldsymbol{C} \boldsymbol{d} \boldsymbol{x} \boldsymbol{2}$ in TS cells. The TS cell line used for this assay is homozygous for $C d x 2$-eGFP and seeded at 20,000 cells per $\mathrm{cm}^{2}$ on Matrigel-coated plates, in TX medium including $25 \mathrm{ng} \mathrm{ml}^{-1} \mathrm{FGF} 4$ and $2 \mathrm{ng} \mathrm{ml}^{-1} \mathrm{TGF} \beta 1$. After $24 \mathrm{~h}$, the medium was replaced by TX medium without FGF4 and TGF $\beta 1$ (blank medium) and candidate molecules were added. PD0325901 (1 $\mu \mathrm{M})$ was used as a negative control to downregulate CDX2 expression (see Extended Data Fig. 2). Cells were assessed for eGFP expression $48 \mathrm{~h}$ after the addition of the candidate molecules, using a BD FACSCalibur. Data were analysed using FlowJo. The basal level of $C d x 2$-eGFP expression was defined by gating the population of TS cells cultured for $48 \mathrm{~h}$ in blank medium (see Extended Data Fig. 3).

Immunohistochemistry. Immunofluorescence was performed as described by the laboratory of J. Rossant (http://lab.research.sickkids.ca/rossant/labresources/). Antibodies were used against CDX2 (MU392A-UC; 1:400 dilution), Nanog (Abcam ab84447; dilution 1:200), OCT4 (Santa Cruz 5279; 1:200 dilution), GATA6 (R\&D Systems AF1700; 1:200), PDGFR $\alpha$ (R\&D Systems AF1062; 1:150 dilution), ELF5 (Santa Cruz sc-9645; 1:250 dilution), MASH2 (also known as ASCL2; Genetex GTX60272; 1:250 dilution), TEAD4 (Abcam ab58310; 1:400 dilution) and proliferin (E10, Santa Cruz sc-271891; 1:250 dilution), TPBPA (Abcam ab104401; 1:250 dilution), placenta lactogen (P17, Santa Crux, sc-34713; 1:200 dilution), HAND1 (Abcam ab115256; 1:250 dilution), and E-cadherin clone DECMA-1 (Sigma U3254; 1:500 dilution). All images were taken using a PerkinElmer Ultraview VoX spinning disk microscope combined with a Leica SP8. Derivation of de novo ES and TS cell lines from blastoids and injection into blastocysts. Blastoids cultured for $65 \mathrm{~h}$ and freshly isolated E3.5 blastocysts (E3.5 $\mathrm{CBA} \times \mathrm{C} 57 \mathrm{BL} / 6)$ were individually transferred into wells of 96-well plates containing mouse embryonic fibroblasts. TS cell lines were derived in TS medium containing $20 \% \mathrm{FBS}, 25 \mathrm{ng} \mathrm{ml}^{-1} \mathrm{FGF} 4,2 \mathrm{ng} \mathrm{ml}^{-1} \mathrm{TGF} \beta 1$ and $1 \mu \mathrm{g} \mathrm{ml}^{-1}$ heparin, as described previously ${ }^{2}$. ES cell lines were derived in B27N2 medium supplemented with $10 \mathrm{ng} \mathrm{ml}^{-1} \mathrm{LIF}, 1 \mu \mathrm{M}$ PD0325901 and $3 \mu \mathrm{M}$ CHIR99021 (2i medium). The derivation was considered successful if colonies appeared on passage two after blastocyst or blastoid plating. ES or TS cells (12-15 cells) were injected into E3.5 blastocysts from C57BL/6 mice. The injected blastocysts were transferred into the uterus of $\mathrm{CBA} \times \mathrm{C} 57 \mathrm{BL} / 6$ pseudo-pregnant females. Embryos were explanted from the uterus and dissected from the deciduae at E6.5.

Uterus transfer. Pseudo-pregnant $F_{1}$ females were selected for oestrous and placed with vasectomized males in the evening. Mice were considered to mate at midnight, and the next morning, plugged females were separated. Blastoids and trophospheres were cultured and selected as described above, and 25 blastoids or trophospheres were injected into both horns of the uterus of day E3.3-E3.5 pseudo-pregnant Bl6/CBA females. The blastoids and trophospheres were transferred on the ovary side of the uterus, using a medium containing LIF. Uteri were explanted on day E6.5 or E7.5, fixed in 4\% paraformaldehyde and processed for paraffin embedding and histology.

qRT-PCR. RNA was obtained using TRIzol reagent (Thermo Scientific 15596-018) extraction method. Retrotranscription was performed using the Superscript III kit (Invitrogen 18080-044). Quantitative PCR was performed using IQ SYBR Green Supermix (Bio-Rad 1708880) and $30 \mathrm{ng}$ of RNA using the following gene-specific primers: $C d x 2$ : 5' -AAAGTGAGCTGGCTGCCACACTTG-3', 5'-TCCATC AGTAGATGCTGTTCGTGG-3'; Tcfap2c: 5'-GAGGTGCAGAATGTGGACGA-3', 5'-CCCCAAAGGGTTCTTGGTCA-3'; Tead4: 5'-TTGAGCGAAGCTT CCAGGAG-3', 5' -TTCCGACCATACATCTTGCCT-3'; Gata3: 5'-GCTCCTTGC TACTCAGGTGAT-3', 5'-GGAGGGAGAGAGGAATCCGA-3'; Eomes: 5' TGATCATCACCAAACAGGGC-3' $5^{\prime}$-ACTGTGTCTCTGAGAAGGTG-3'; Elf5: 5'-TTCGCTCGCAAGGTTACTCC-3', 5' - TGTTCGGCTGTGACAGTCTT-3'; Hand 1: 5'-GCCTACTTGATGGACGTGCT-3', 5' -TGCTGAGGCAACTCCCT TTT-3'; $C d h 1: 5^{\prime}$-CCAAGCACGTATCAGGGTCA-3' ${ }^{\prime}, 5^{\prime}$-ACTGCTGGTCAGGAT CGTTG-3'; Id $2: 5^{\prime}$-CCTGCATCACCAGAGACCTG-3' ${ }^{\prime} 5^{\prime}$-GGGAATTCAGATGC CTGCAA- ${ }^{\prime}$; Sox $2: 5^{\prime}$-GATCAGCATGTACCTCCCCG-3' ${ }^{\prime}, 5^{\prime}$ - CTGGGCCA TGTGCAGTCTAC-3 $3^{\prime}$; Act $b 5^{\prime}$-TGTCGAGTCGCGTCCACC-3' 5 $^{\prime}$-TCGTCAT CCATGGCGAACTGG-3' 
RNA sequencing. Blastocysts were flushed from the uterus of CBA $\times$ C57BL/6 E3.5 mice and sorted as E3.25 or E3.5 blastocysts according to their phenotype: early blastocysts had a smaller number of cells, a smaller diameter, a smaller blastocoel and a more prominent ICM than late blastocysts. Blastoids were formed using $\mathrm{F}_{4}$ wild-type or $\mathrm{GFP}^{+} \mathrm{TS}$ cells and V6.5 wild-type or H2B-RFP ES cells. For the bulk sequencing, blastocysts or blastoids $(n=50)$ were pooled into TRIzol. The transcriptional profile of virtual blastoids was determined by combining in silico, at a 1:3.5 ratio, ES and TS cells cultured in 2D, in blastoid medium, for $65 \mathrm{~h}$. For single-cell sequencing, blastoids or Tyrod's acid treated, zona-free, blastocysts were sequentially exposed to $0.3 \mathrm{mg} \mathrm{ml}^{-1}$ collagenase IV (Gibco, 17104019) and a 1:3 dilution of Tryple Express Select X10 (Thermofisher A1217701), and subsequently dissected with glass capillaries of different diameters ranging from 100 to $20 \mu \mathrm{m}$. Single cells were FACS-sorted into 384-well plates as described previously $^{33}$. For this analysis, we analysed a total of 1,577 cells including 290 parental TS cells cultured in 2D in TX medium; 316 parental ES cells cultured in 2D in $2 \mathrm{i}$ medium; 367 blastoid cells; 336 TS cells cultured alone in blastoid medium within microwells, which formed trophospheres; 268 ES cells cultured alone in blastoid medium within microwells, which formed embryoid bodies; and 60 blastocyst cells extracted from three different E3.5 blastocysts.

CEL-Seq library preparation. For the bulk sequencing experiment (Fig. 3a), the whole RNA from blastocysts and blastoids was extracted from TRIzol. For cell lines, $20 \mathrm{ng}$ of total extracted RNA was used as starting material, as measured by Qubit RNA assay (Life Technologies). All samples were processed using CELSeq2 protocol $^{34}$, the CEL-Seq1 primers ${ }^{35}$ and the Life Technologies Ambion kit (AM1751) as previously described ${ }^{36}$. For the single-cell sequencing experiments, cells were processed according to the SORT-seq method, as previously described ${ }^{33}$ and clustered using the Race-ID method, as previously described ${ }^{36} . t$-SNE map representation of transcriptome similarities was based on 1,577 cells collected from parental ES cells cultured in 2D in 2i medium ( 316 cells), parental TS cells cultured in 2D in TX medium ( 290 cells), blastoid cells ( 367 cells), TS cells cultured in blastoid medium within microwells (that is trophospheres, 336 cells), ES cells cultured in blastoid medium within microwells (that is embryoid bodies, 268 cells). Libraries were sequenced on an Illumina Nextseq 500 using 75-bp high output paired-end sequencing. Transcription factors were selected according to the Riken transcription factor database, and lowly expressed ones were filtered out before plotting the heat maps. Differential expression analysis was done using the DESeq package ${ }^{37}$, and pathway enrichment analysis was done using DAVID ${ }^{38}$ and Gorilla ${ }^{39}$.

Gene set enrichment analysis. Analysis was performed according to the standard procedure of gene set enrichment analysis (GSEA) analysis (http://software.broadinstitute.org/gsea/). The gene set was established by extracting genes that were differentially regulated between the cells of the trophectoderm of blastocysts ( 27 cells) and TS cells ( 33 cells). The pre-ranked list of genes differentially expressed between the trophoblasts of blastoids ( 59 cells) and TS cells ( 33 cells) was established by extracting all the genes that were differentially regulated between clusters established using the RaceID clustering. These populations were defined based on the RaceID clustering. The gene set consisted of 281 genes differentially regulated and with $P<0.05$.

Curated gene sets. Curated gene sets were used to identify, within the list of GSEA enriched genes, genes related the TGF $\beta$ signalling pathway or to epithelial cells (highlighted in red and green, respectively, in Supplementary Table 1 sheet 5). The gene set for the TGF $\beta$ pathway was composed of the GSEA gene sets: reactome signalling by TGF $\beta$ receptor complex; KEGG TGF $\beta$ signalling pathway; Biocarta TGF $\beta$ pathway, and PID SMAD2/3 nuclear pathways. The gene set for the epithelial cells was composed of the GO gene sets: GO:0002066; GO:0002065; GO:0090136; GO:0002064; GO:0030855; GO:0072148; GO:0002070; GO:0003382; GO:0050673; and GO:0060429.

Whole-mount single-molecule FISH. The Affymetrix ViewRNA ISH Cell Assay Kit was used to perform whole-mount single-molecule FISH on freshly isolated E3.5 blastocysts. The probe used was designed to hybridize against Id2 (catalogue VB6-10967), Bmp4 (catalogue VB1-13681), Nodal (catalogue VB6-18786), and Il11 (catalogue VB6-19190-VC) mRNA. Blastocysts were imaged in steps of $0.5-\mu \mathrm{m}$ using a $63 \times$ objective on a PerkinElmer Ultraview VoX spinning disk microscope combined with a Leica SP8.

BMP4 and Nodal screens. The screen was performed by adding proteins within the blastoid medium at both 0 and $48 \mathrm{~h}$. Images were acquired over 800 microwells per condition. The yield of blastoids (Fig. 4b) is measured as described in the 'Culture of blastoids' section. The yield of cystic structures (Figs. $4 \mathrm{~d}$ and 5) is measured as the percentage of microwells that contained a structure with a cavity that has a maximal diameter $>20 \mu \mathrm{m}$. The diameter of cystic structures (Fig. 4e) is measured by image analyses using the microscope measurement tool, Fiji, by measuring the larger diameter of the larger cavity within each microwell. The circularity is measured using Fiji, as follows: (circularity $=4 \pi\left(\right.$ area/perimeter $\left.\left.{ }^{2}\right)\right)$. Combinations of BMP 4 and Nodal were: $5 \mathrm{ng} \mathrm{ml}^{-1} \mathrm{BMP} 4+5 \mathrm{ng} \mathrm{ml}^{-1}$ Nodal; $5 \mathrm{ng}$ $\mathrm{ml}^{-1} \mathrm{BMP} 4+45 \mathrm{ng} \mathrm{ml}^{-1}$ Nodal; $45 \mathrm{ng} \mathrm{ml}^{-1} \mathrm{BMP} 4+5 \mathrm{ng} \mathrm{ml}^{-1}$ Nodal; $45 \mathrm{ng} \mathrm{ml}^{-1}$ BMP4 $+45 \mathrm{ng} \mathrm{ml}^{-1}$ Nodal.

CRISPR knockout. Two guide RNAs (gRNAs) were designed to flank the first exon of Nodal or the first two exons of the Klf6 gene. ES and TS cells were transfected with a plasmid for expression of Cas9 protein, gRNAs and the puromycin-resistance gene. ES cells were transfected in 2D feeder-free conditions; TS cells were transfected in suspension for $4 \mathrm{~h}$. Both ES and TS cells were subsequently plated on mouse embryonic fibroblasts. Puromycin was added $24 \mathrm{~h}$ after transfection to the culture media to apply selection during the following $48 \mathrm{~h}$. Colonies were allowed to grow until they were able to be picked, then screened for deletion of the region of interest.

Reporting summary. Further information on experimental design is available in the Nature Research Reporting Summary linked to this paper.

Data availability. Data generated during the study are available in the Supplementary Tables and in the Gene Expression Omnibus (GEO) public repository under accession GSE99786.

30. Tesar, P. J. et al. New cell lines from mouse epiblast share defining features with human embryonic stem cells. Nature 448, 196-199 (2007).

31. Rivron, N. C. In vitro generation of blastoids from trophoblast stem cells and embryonic stem cells. Protoc. Exch. https://doi.org/10.1038/protex.2018.051 (2018).

32. van de Wetering, M. et al. The $\beta$-catenin/TCF- 4 complex imposes a crypt progenitor phenotype on colorectal cancer cells. Cell 111, 241-250 (2002).

33. Muraro, M. J. et al. A single-cell transcriptome atlas of the human pancreas. Cell Syst. 3, 385-394.e3. (2016).

34. Hashimshony, T. et al. CEL-Seq2: sensitive highly-multiplexed single-cell RNA-Seq. Genome Biol. 17, 77 (2016)

35. Hashimshony, T., Wagner, F., Sher, N. \& Yanai, I. CEL-Seq: single-cell RNA-Seq by multiplexed linear amplification. Cell Reports 2, 666-673 (2012).

36. Grün, D. et al. Single-cell messenger RNA sequencing reveals rare intestinal cell types. Nature 525, 251-255 (2015).

37. Anders, S. \& Huber, W. Differential expression analysis for sequence count data. Genome Biol. 11, R106 (2010).

38. Dennis, G., Jr et al. DAVID: Database for Annotation, Visualization, and Integrated Discovery. Genome Biol. 4, 3 (2003).

39. Eden, E., Navon, R., Steinfeld, I., Lipson, D. \& Yakhini, Z. GOrilla: a tool for discovery and visualization of enriched GO terms in ranked gene lists. BMC Bioinformatics 10, 48 (2009).

40. Vrij, E. J. et al. 3D high throughput screening and profiling of embryoid bodies in thermoformed microwell plates. Lab Chip 16, 734-742 (2016).

41. Nakamura, T. et al. SC3-seq: a method for highly parallel and quantitative measurement of single-cell gene expression. Nucleic Acids Res. 43, e60 (2015).

42. Kolodziejczyk, A. A. et al. Single cell RNA-sequencing of pluripotent states unlocks modular transcriptional variation. Cell Stem Cell 17, 471-485 (2015).

43. Qiu, D. et al. Klf2 and Tfcp2/1, two Wnt/3-catenin targets, act synergistically to induce and maintain naive pluripotency. Stem Cell Reports 5, 314-322 (2015).

44. Morgani, S. M. et al. Totipotent embryonic stem cells arise in ground-state culture conditions. Cell Rep. 3, 1945-1957 (2013).

45. Hussein, S. M., Duff, E. K. \& Sirard, C. Smad4 and $\beta$-catenin co-activators functionally interact with lymphoid-enhancing factor to regulate graded expression of Msx2. J. Biol. Chem. 278, 48805-48814 (2003).

46. Labbé, E. et al. Transcriptional cooperation between the transforming growth factor- $\beta$ and Wnt pathways in mammary and intestinal tumorigenesis. Cancer Res. 67, 75-84 (2007). 
a
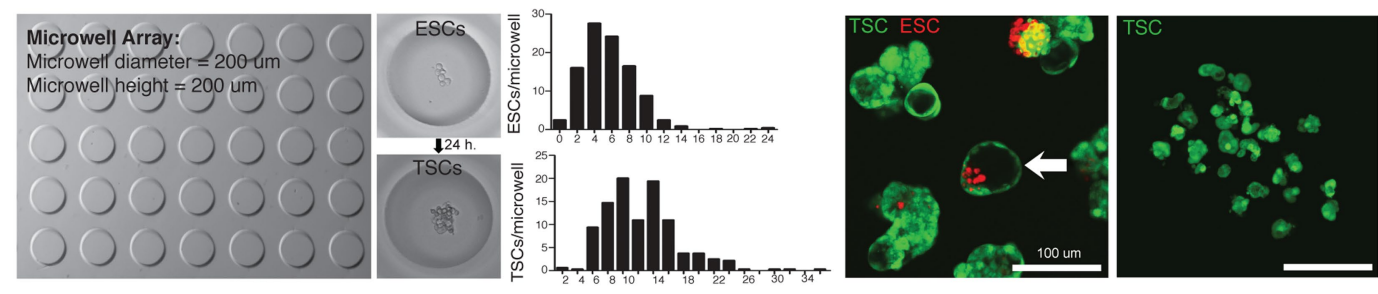

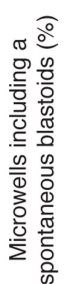

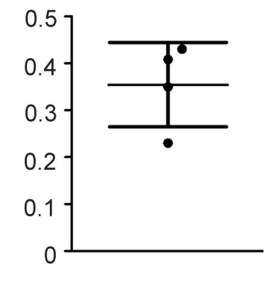

C

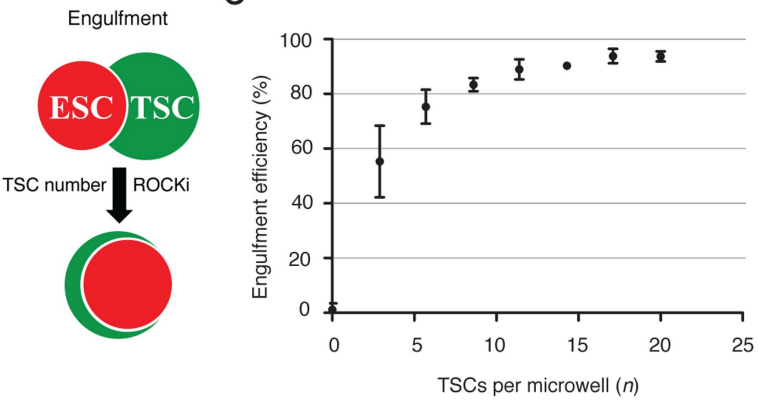

d

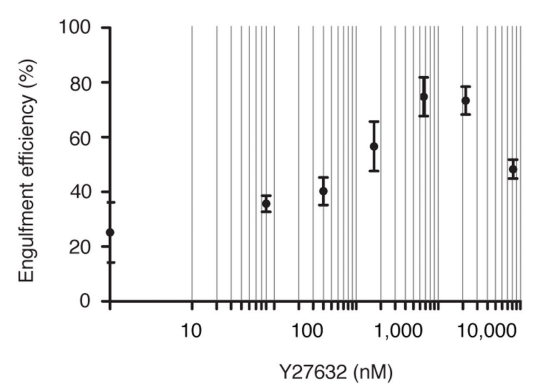

$-Y 27632$

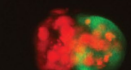

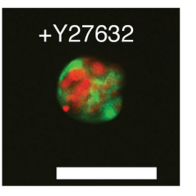

e
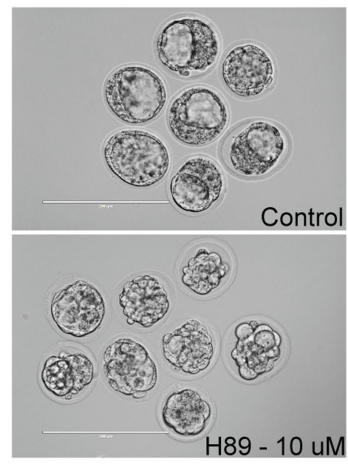

Morula stage: Add inhibitors ( $t=0$ hours) Blastocyst stage: Image ( $\mathrm{t}=24$ hours)
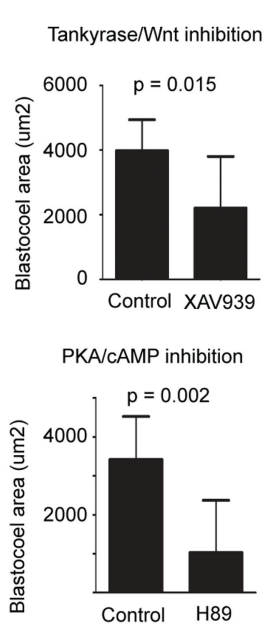

\section{f}

f Wnt ligands in blastocysts and stem cells

g

Wnt activity reporter: Tcf activity

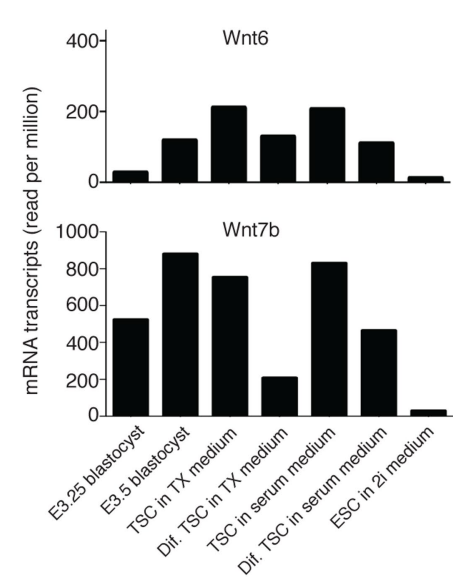

i

h
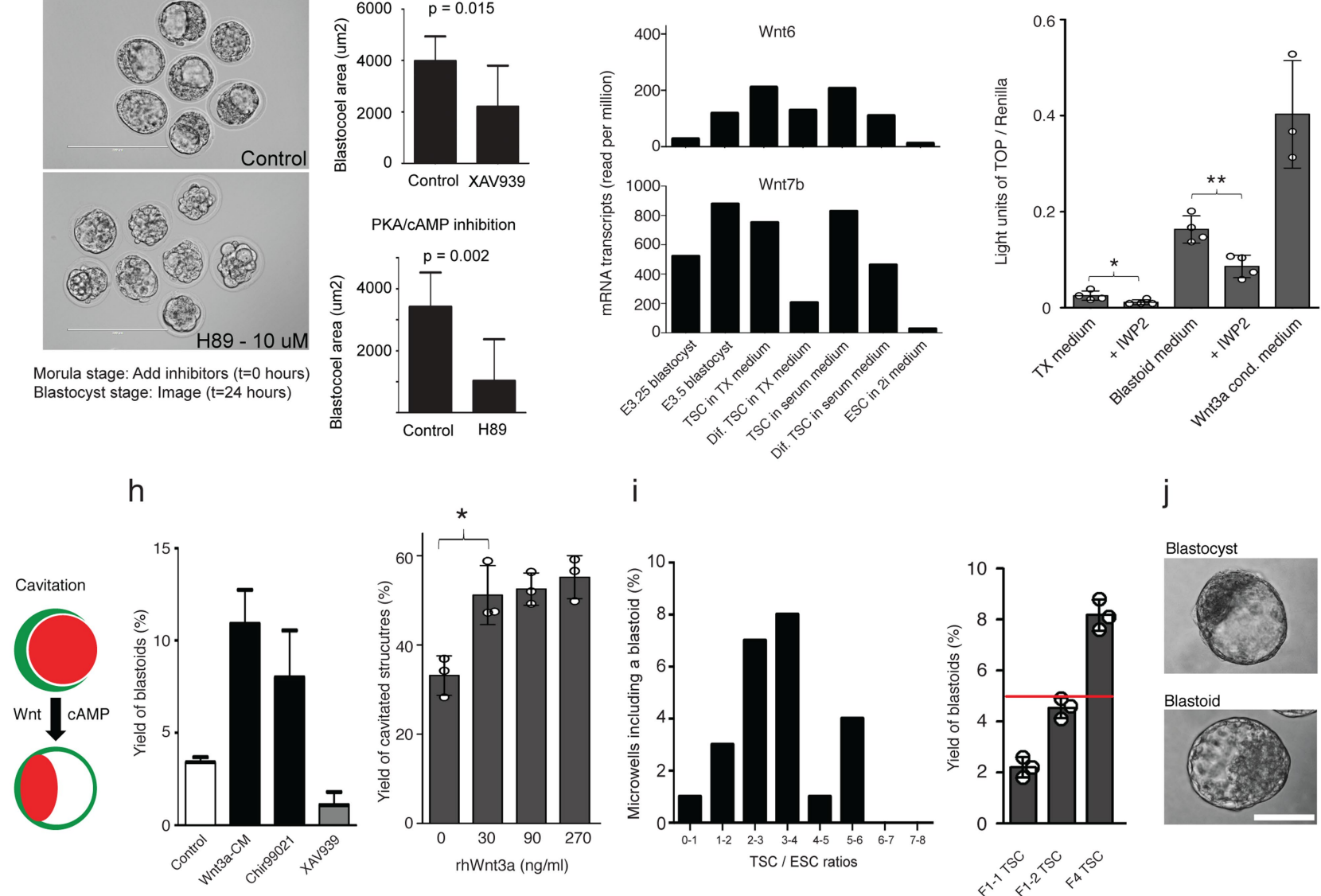

j

Extended Data Fig. 1 | See next page for caption. 
Extended Data Fig. 1 | In vitro formation of blastoids. a, Nonadherent hydrogel microwell arrays were formed by replica molding using polydimethylsiloxane (PDMS) stamps as previously described ${ }^{7,8,40}$. The array used for 12-well plates contains 1,000 cylindrical structures of $200 \mu \mathrm{m}$ diameter and height. Upon cell seeding, owing to the nonadherent properties of the hydrogel, all cells slide into the microwells. Upon settling, the number of ES cells per microwell follows a distribution. Mean number per microwell: 5.2; half of the microwells contained between 4 and 6 cells per microwell (right, top). Upon aggregation of ES cells (24-36h depending on the cell line), TS cells were seeded. Mean number per microwell: 12; half of the microwells contained between 10 and 14 cells (right, bottom; time point $0 \mathrm{~h}$ ). b. After culture in blank medium (see Methods), TS and ES cells mostly arranged into non-organized structures forming trophoblasts cysts. TS cells cultured without ES cells $(65 \mathrm{~h})$ formed fewer cystic structures than a co-culture. Rarely, TS cells enclosed ES cells and formed regular cystic structures morphologically similar to the blastocyst (white arrow). $n=4$ independent microwell arrays. Structures shown in $\mathbf{b}$ were taken out of the microwell array at $65 \mathrm{~h}$. Scale bars, $100 \mu \mathrm{m}$. c, d, Optimization of the engulfment of ES cells by TS cells. c, Dosing the number of TS cells. ES cells were seeded at $t=-24 / 36 \mathrm{~h}$. At $t=0 \mathrm{~h}$, different numbers of TS cells were seeded on top of the ES cell aggregates. After $24 \mathrm{~h}$, the engulfment efficiency was defined by measuring the percentage of coverage of TS cells around ES cells. The most efficient yields were observed when more than $12 \mathrm{TS}$ cells were added to ES cell cultures. $n=250$ independent microwells. The centre value is the mean, error bars are s.d. d, Left, optimization of the concentration of Y27632. At $t=0 \mathrm{~h}$, different concentrations of Y 27632 were added. At $t=24 \mathrm{~h}$, the engulfment efficiency was measured as the percentage of coverage of TS cells around ES cells. The most efficient yields were obtained with $20 \mu \mathrm{M}$ Y27632. $n=250$ independent microwells. The centre value is the mean. Right, optimized engulfment. Images of ES cells (red) engulfed by TS cells (green) using the optimized conditions (mean of 12 TS cells per microwell and $20 \mu \mathrm{M}$ Y27632, 80\% engulfment efficiency). Images are representative of three independent experiments. Scale bar, $100 \mu \mathrm{m}$. Error bars are s.d. e, Blastocoel area of blastocysts formed from E2.5 CBA $\times$ C57BL/6 morula, selected for initiation of compaction and cultured in M16 medium for $24 \mathrm{~h}$ along with antagonists of WNT (XAV939, $15 \mu \mathrm{M})$, PKA $(\mathrm{H} 89,10 \mu \mathrm{M})$ or DMSO $(1: 1,000$, control). $n=10$ independent blastocysts. $P=0.015$ and $P=0.002$, twosided Student's $t$-test. The centre values are medians. Errors bars are s.d. f, RNA-sequencing data for Wnt 6 and $W n t 7 b$, in E3.25 and E3.5 blastocysts, TS cells (TSC) and ES cells (ESC). TS cells were cultured in serum-free (TX) or serum-rich (TS) medium (see Methods). Differentiation was induced by the removal of growth factors. g, TCF luciferase assay for WNT activity in TS cells (see Methods). WNT secretion was blocked using IWP2 $(2.5 \mu \mathrm{M}) . n=4$ independent biological samples of TS cell culture. ${ }^{*} P=0.045, * * P=0.0057$, two-sided Student's $t$-test. The centre values are medians. Errors bars are s.d. h, Induction of cavitation. Blastoids were defined as described in the Methods. ES and TS cells were seeded in serum-free TX medium including Y27632 $(20 \mu \mathrm{M})$ and a WNT modulator. WNT3A-conditioned medium $(50 \%$ of the total volume), CHIR99021 $(3 \mu \mathrm{M})$, or the combination of CHIR99021 $(3 \mu \mathrm{M})$ and XAV $939(15 \mu \mathrm{M})$ was added at the time of TS cells seeding $(t=0 \mathrm{~h})$. $n=3$ independent microwell arrays. $* P=0.017$, two-sided Student's $t$-test. The centre values are medians. Errors bars are s.d. i, Yield of blastoids depending on the initial ratio of TS to ES cells, at $t=0 \mathrm{~h}$, within individual microwells (left). Yield of blastoids formed using three lines of TS cells representative of the scope of efficiency observed (right). Different lines were isolated upon $\mathrm{CBA} \times \mathrm{C} 57 \mathrm{BL} / 6$ matings $\left(\mathrm{F}_{1-1}, \mathrm{~F}_{1-2}\right.$, derived by N.R.) and ICR $\times$ ICR matings ( $\mathrm{F}_{4}$, provided by J. Rossant). $n=3$ independent microwell arrays. The centre values are the mean. Error bars represent s.d. The red line represents the median of the three cell lines (5\% of the total number of microwell per array). $\mathbf{j}$, Bright-field images of a representative E3.5 blastocyst (top) and a blastoid (bottom). Scale bar, $50 \mu \mathrm{m}$. 
a

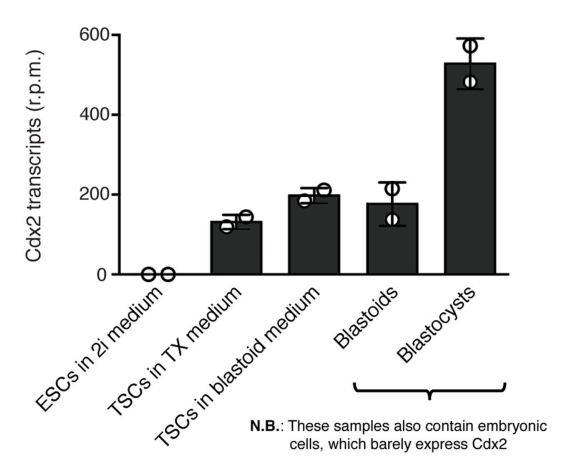

C

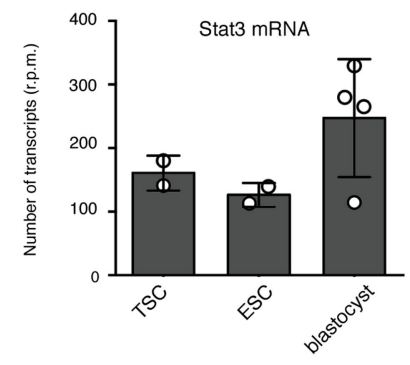

b

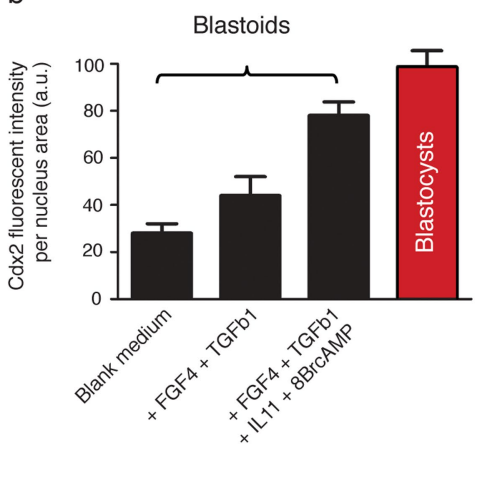

e Exposure of TSCs to the GP130 chemical inhibitor SC144 (reported IC50 $=0.72 \mu \mathrm{M}$ )
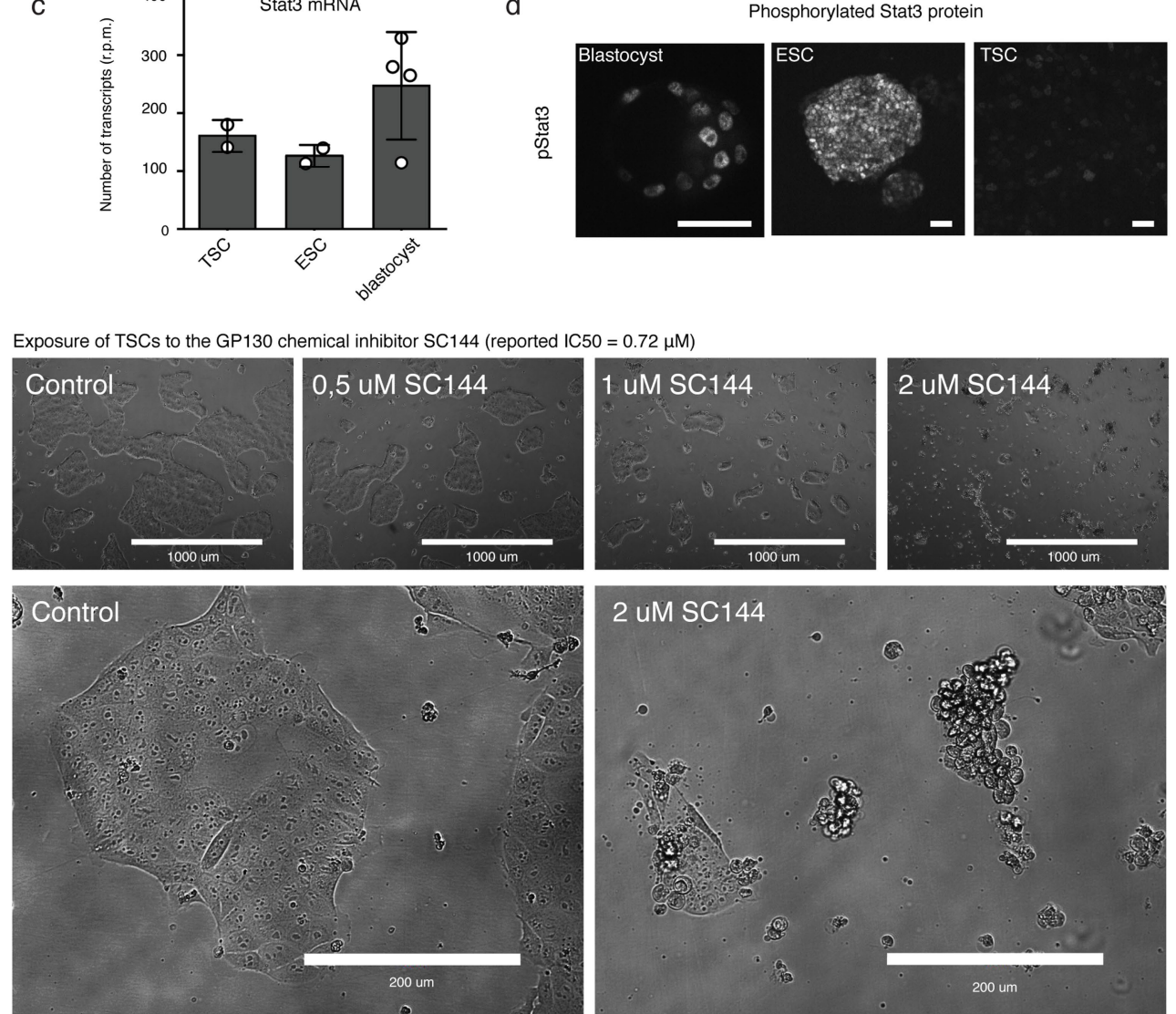

f
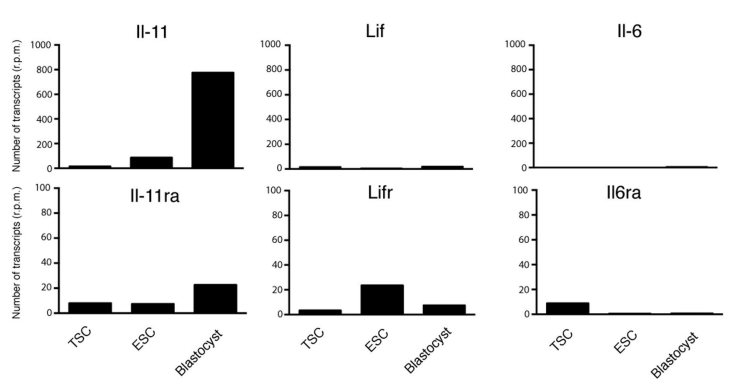

g

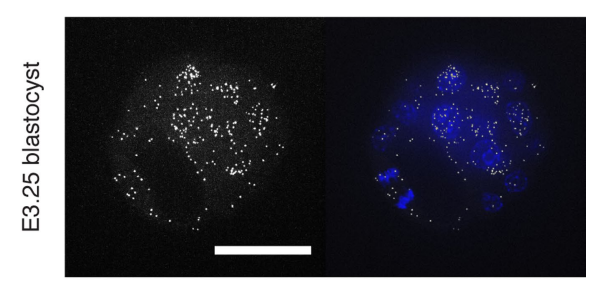

IL11 mRNA IL11 mRNA + Hoechst

Extended Data Fig. 2 | See next page for caption. 
Extended Data Fig. 2 Regulation of trophoblast cells. a, The number of $C d x 2$ transcript reads per million mapped reads (r.p.m.) as measured in bulk samples of: ES cultured in 2i medium and TS cells cultured in TX medium, TS cells cultured in blastoid medium, and blastoids and blastocysts. Note that the blastoids and blastocysts comprise both trophectoderm and ICM cells, the latter expressing only very low levels of $C d x 2 . n=2$ independent biological samples (see Methods). b, Measurement of CDX2 fluorescent intensity in blastoids and blastocysts. Blastoids were fixed and stained with an anti-CDX2 antibody (see Methods). E3.5 blastocysts were used as a positive control. $n=15$ independent blastoids or blastocysts. Error bars are s.d. c, The number of
Stat 3 transcripts per million reads as measured in bulk samples of ES and TS cells and blastocysts. d, Immunostaining for phosphorylated STAT3 in a representative blastocyst colony of ES and TS cells (see Methods). Scale bar, $50 \mu \mathrm{m}$. e, TS cells cultured in the presence of different concentrations of the STAT/GP130 pathway inhibitor SC144. Both growth and viability were affected by concentrations of at least $1 \mu \mathrm{M}$. $\mathbf{f}$, The number of transcripts per million reads for the STAT pathway ligands Il11, Lif and Il6, along with their receptors, as measured in bulk samples of ES cells, TS cells and blastocysts. g, Whole-mount single-molecule FISH for Il11, in an E3.25 blastocyst. Scale bar, $50 \mu \mathrm{m}$. See Methods for further details. 
a

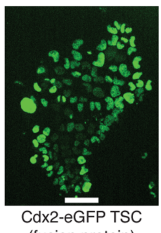

b

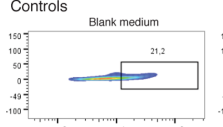

Blank medium +8 Br-cAMP

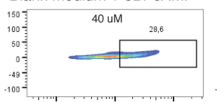

$\begin{array}{cc}10^{0} & 10^{1} \\ 10^{2} \\ 0^{2}\end{array}$
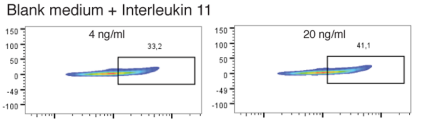

Factor

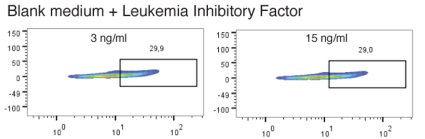

Blank medium + Bone Morphogenetic Protein 4
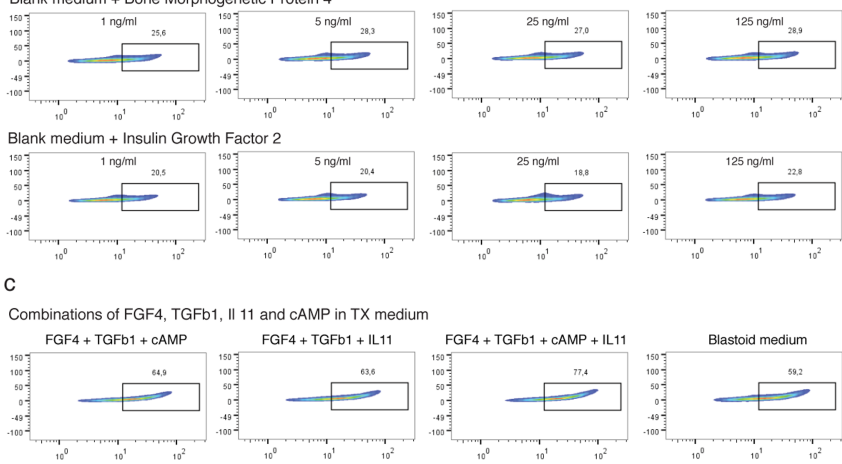
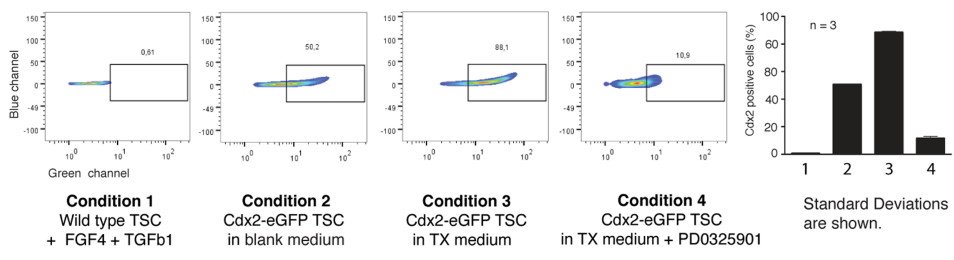

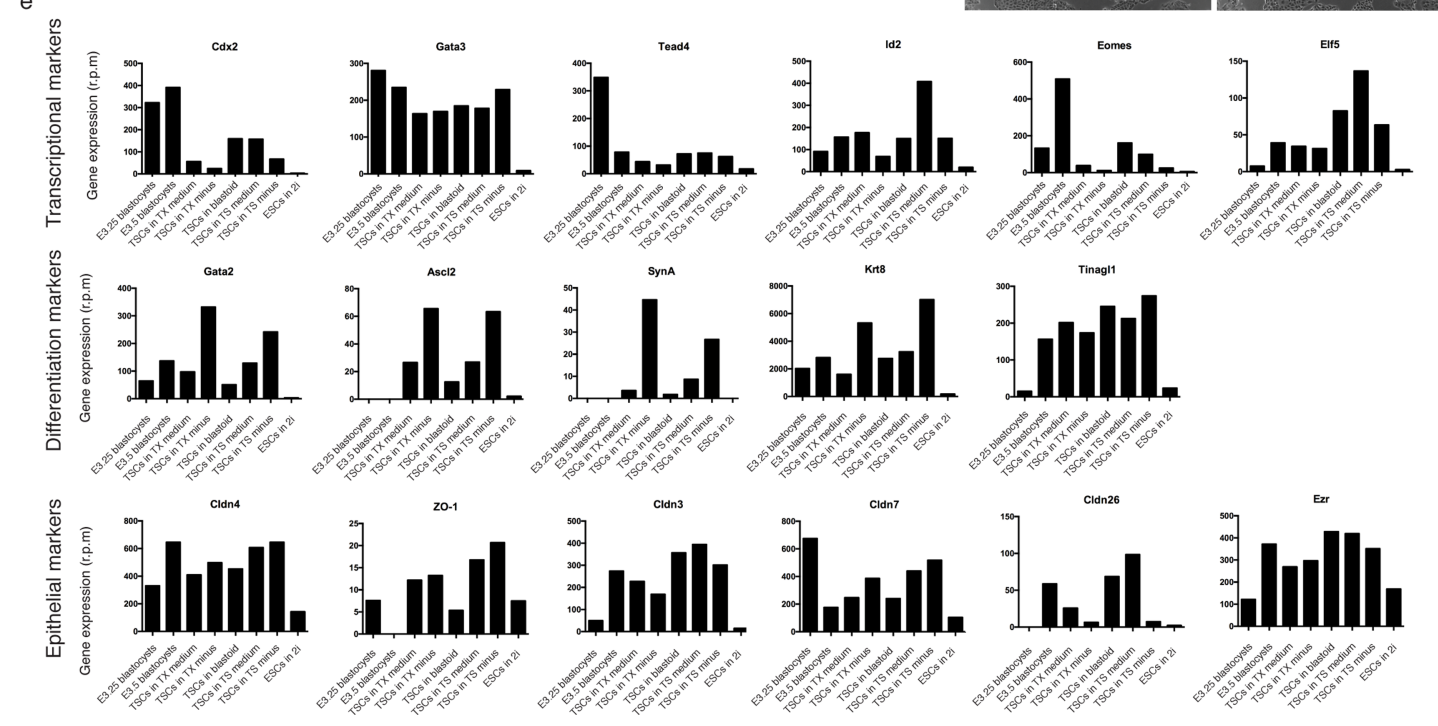

Extended Data Fig. 3 | See next page for caption.

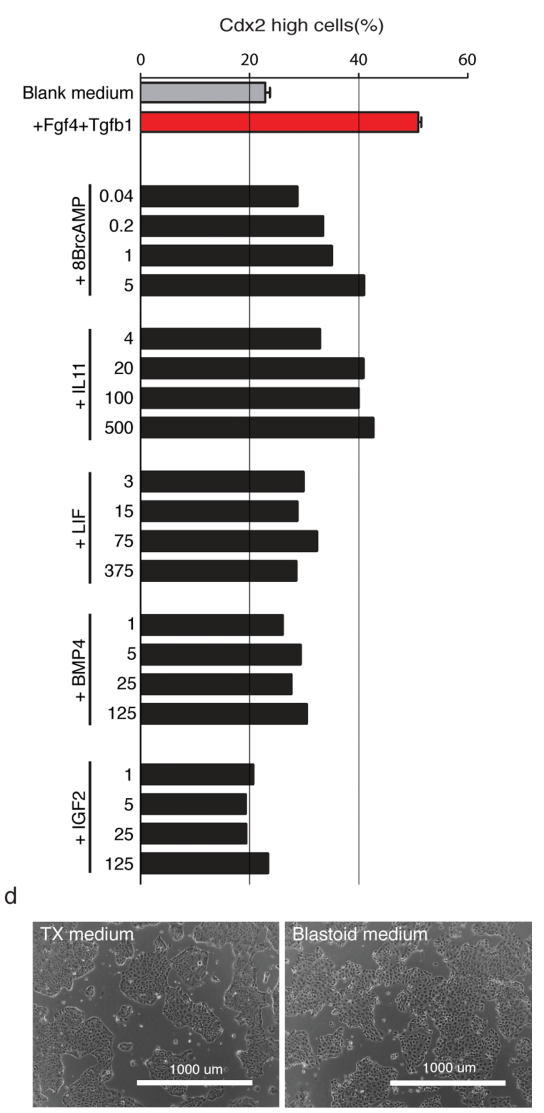


Extended Data Fig. 3 Screen for regulators of CDX2 expression in TS cells. a, Calibration of the cell lines. The assay is performed using $\mathrm{CDX}^{-}-\mathrm{eGFP}^{+}$TS cells and as described in the schematic and the Methods. For the initial calibration of the assay, gating was set so that wild-type TS cells do not appear in the gate (non-specific fluorescence, left FACS plot). In that condition, after $48 \mathrm{~h}$, the following appeared in the gate: $50 \%$ of the CDX2-eGFP ${ }^{+}$cells cultured in blank TX medium; $88 \%$ of the CDX2-eGFP ${ }^{+}$TS cells cultured in TX medium including FGF4 $\left(25 \mathrm{ng} \mathrm{ml}^{-1}\right)$ and TGF $\beta 1\left(2 \mathrm{ng} \mathrm{ml}^{-1}\right) ; 10 \%$ of the CDX2-eGFP ${ }^{+}$TS cells cultured in TX medium including FGF4 $\left(25 \mathrm{ng} \mathrm{ml}^{-1}\right), \operatorname{TGF} \beta 1\left(2 \mathrm{ng} \mathrm{ml}^{-1}\right)$ and PD0325901. Biological triplicates show very minor variability $(n=3$ independent biological samples, right). Error bars are s.d. Scale bar, $100 \mu \mathrm{m}$. b. Calibration of the assay and primary screen. For the primary screen of proteins and small molecules, the condition with TX medium including FGF4 and TGF $\beta 1$ was used as a positive control. The gating was set up such that $50 \%$ of these cells appear in the gate. The condition with
TX medium without FGF4 and TGF $\beta 1$ was used as a negative control, and $20 \%$ of these cells appear in the gate. $8 \mathrm{Br}$-cAMP $(0.04$ to $5 \mathrm{mM})$, IL-11 (4 to $500 \mathrm{ng} \mathrm{ml}^{-1}$ ), LIF ( 3 to $375 \mathrm{ng} \mathrm{ml}^{-1}$ ), BMP4 (1 to $125 \mathrm{ng} \mathrm{ml}^{-1}$ ), and IGF2 ( 1 to $125 \mathrm{ng} \mathrm{ml}^{-1}$ ) were added to the medium. The value is the measurement of a single sample. The typical s.d. for this assay is shown in a. c, Secondary screen: combinations of hits. $8 \mathrm{Br}$-cAMP ( $1 \mathrm{mM})$, IL-11 $\left(30 \mathrm{ng} \mathrm{ml}^{-1}\right)$, or $8 \mathrm{Br}$-cAMP $(1 \mathrm{mM})+\mathrm{IL}-11\left(30 \mathrm{ng} \mathrm{ml}^{-1}\right)$ were added to TX medium including FGF4 and TGF. The full blastoid medium was also tested (see Methods). d, e, Markers of multipotency, differentiation and epithelization in stimulated TS cells. TS cells were grown for $48 \mathrm{~h}$ in blank medium (see Methods), TX medium (including FGF4 and TGFß1) or TX medium supplemented with $8 \mathrm{Br}$-cAMP and IL-11. Representative bright-field images of TS cells grown for $48 \mathrm{~h}$ in TX medium or in blastoid medium are shown (d), along with gene expression as characterized using bulk RNA sequencing (e, $n=3)$. Scale bars, $1,000 \mu \mathrm{m}$. 
a

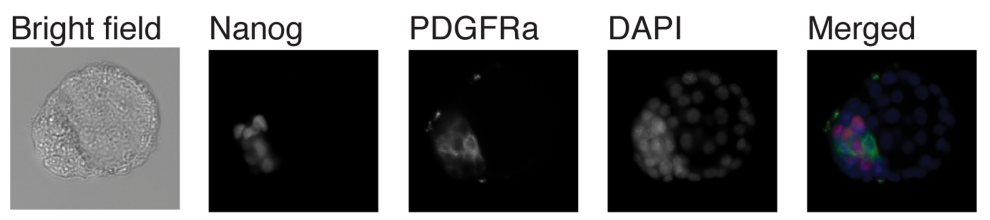

C

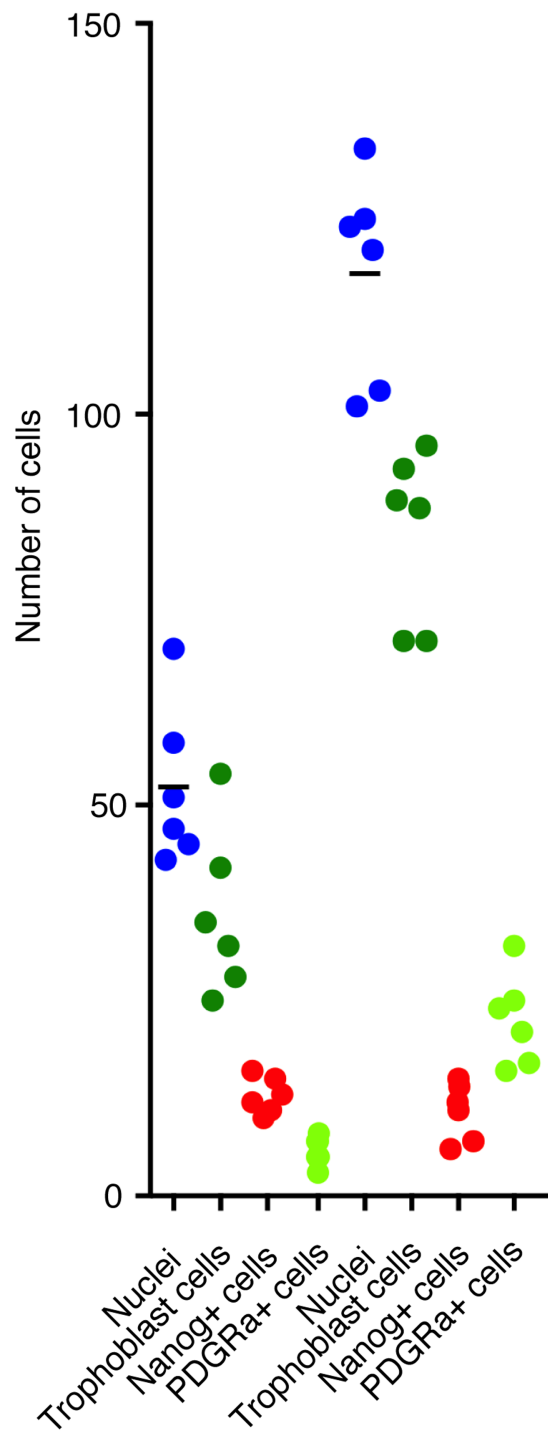

E3.5

E4.5

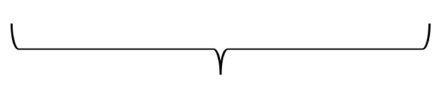

Blastocysts

Extended Data Fig. 4 | Evolution of the number of cells in the blastoid compartments. a, E3.5 and E4.5 blastocysts $(n=6)$ were immunostained using Nanog and PDGFR $\alpha$ antibodies, and nuclei were counterstained with DAPI (see Methods). b, Percentage of blastoids including GATA6 ${ }^{+}$ cells from a total number of 14 blastoids. c, Number of cells in each of the blastoid or blastocyst compartments, namely trophoblast, embryonic and primitive endoderm, were counted based on an immunostaining b

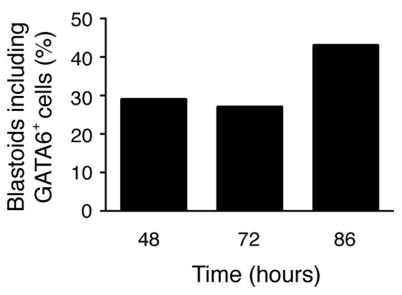


a

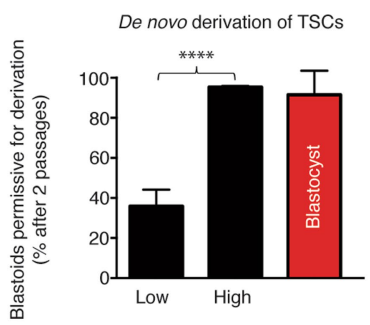

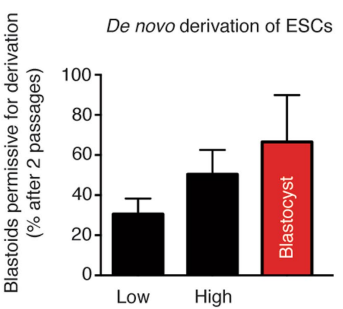

b In utero generation of trophoblasts cell types
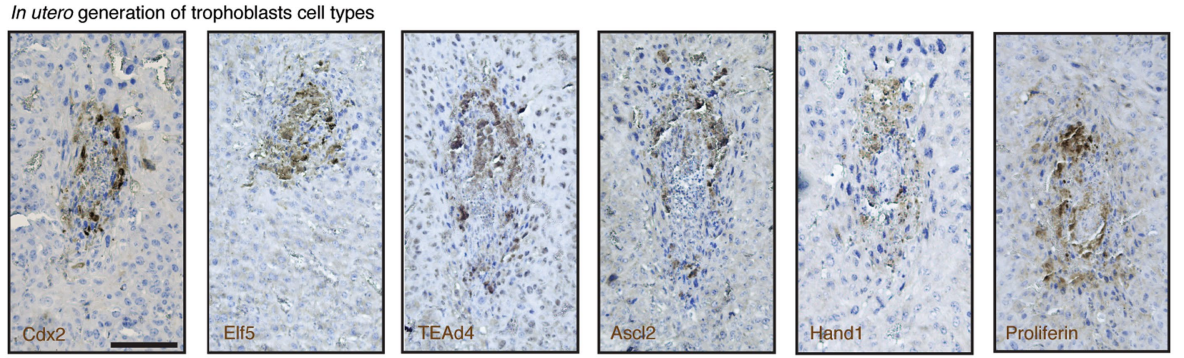

C

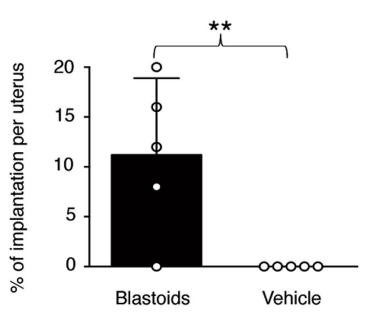

d Decidualization produced by blastocysts, blastoids and oil instillation.

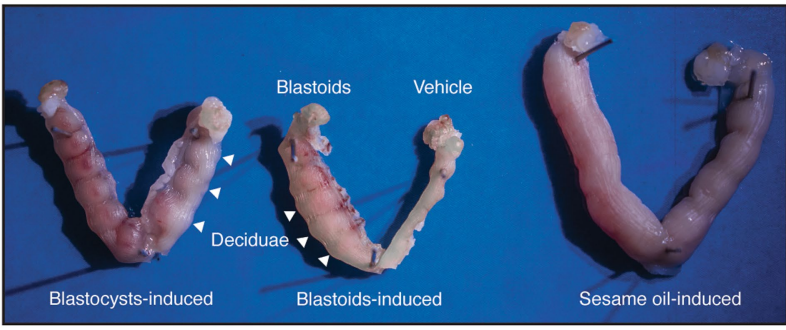

Histology of deciduae produced by blastocysts, blastoids and oil instillation.
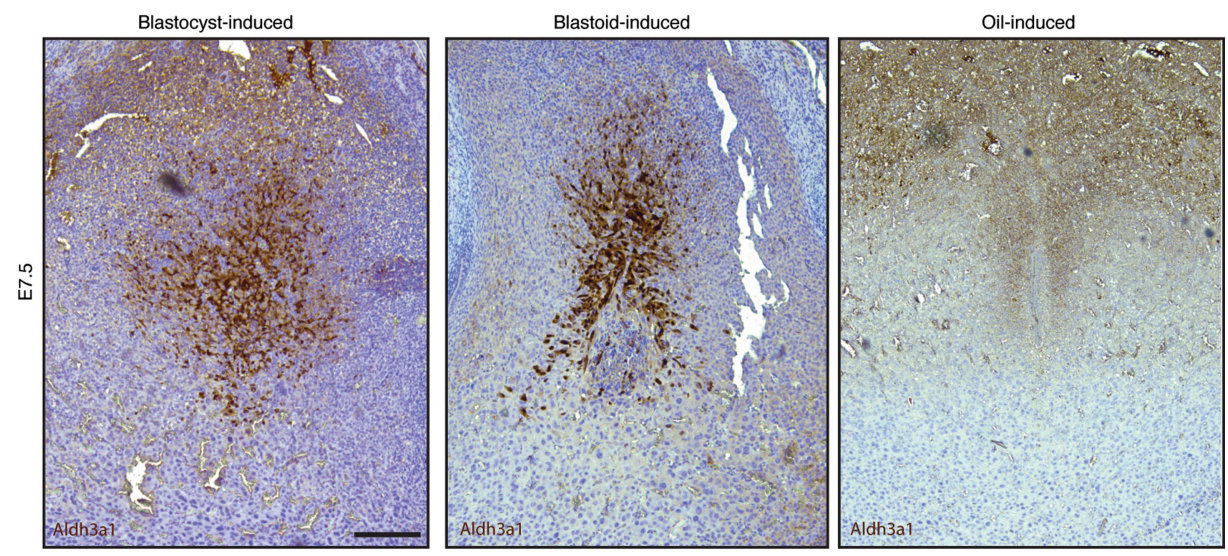

Extended Data Fig. 5 | See next page for caption.
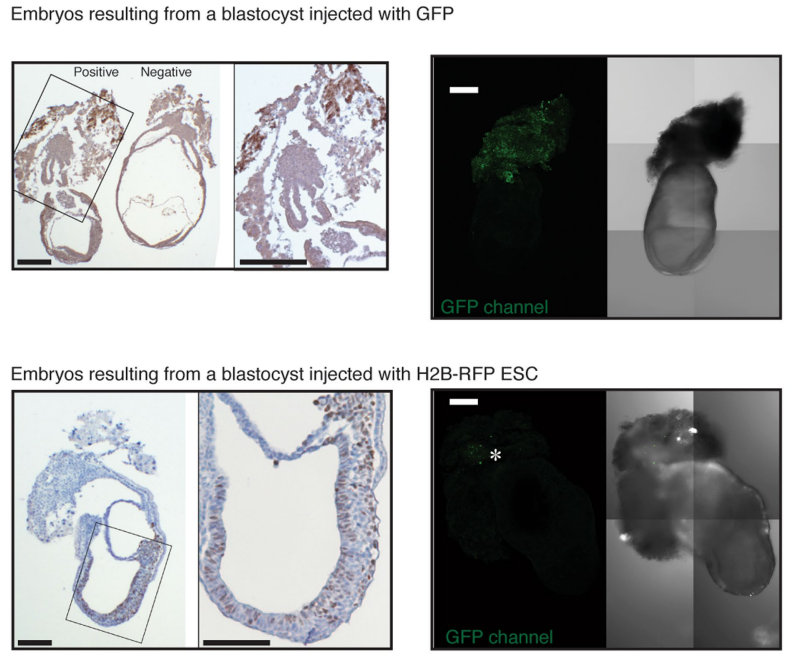

\section{.}


Extended Data Fig. $5 \mid$ De novo derivation and developmental potential of blastoid stem cells. a, De novo TS and ES cell lines were derived from CDX2-high and CDX2-low blastoids, and blastocysts (see Methods). The derivation was considered successful if colonies appeared on passage 2 after blastocyst or blastoid plating. The derivation efficiency of TS cells from CDX2-high blastoids was significantly higher $(* * * * P=0.0001$, Student's $t$-test) than CDX2-low blastoids and similar to blastocysts (left). $n=22$ independent blastoids. Error bars are s.d. The potential of de novo-derived cell lines to chimaerize embryos was assessed by immunohistochemistry, using an anti-GFP antibody targeting GFP ${ }^{+}$ TS cells or an anti-RFP antibody targeting $\mathrm{H} 2 \mathrm{~B}-\mathrm{RFP}^{+}$ES cells (middle). Autofluorescence (denoted by an asterisk), probably due to the presence of blood, occurs within the ecto-placental cone of chimaeric embryos but is lower than the fluorescence recorded from chimaeric embryo after the injection of $\mathrm{GFP}^{+}$TS cells (right). The top image shows a chimaeric embryo after the injection of $\mathrm{GFP}^{+}$TS cells. The bottom image shows a chimaeric embryo after the injection of $\mathrm{H} 2 \mathrm{~B}-\mathrm{RFP}^{+} \mathrm{ES}$ cells. Both embryos are imaged in the GFP channel. Note the presence of a small patch of autofluorescence (denoted by an asterisk) in the bottom image. Microscope settings were adjusted to limit the acquisition of autofluorescence, and images taken upon excitation with a $450-490 \mathrm{~nm}$ (green) laser. Scale bars, $100 \mu \mathrm{m}$. This experiment is a representation of three similar experiments. $\mathbf{b}$, Immunohistochemistry using antibodies against CDX2, ELF5, TEAD4, ASCL2, HAND1 and proliferin, within tissue sections of a representative deciduae including a blastoid grown in utero. Scale bar, $100 \mu \mathrm{m}$. This experiment is a representation of three similar experiments. c, Percentage of implantation sites in uterus transferred with blastoids and vehicle medium at E3.3-E3.5, and explanted at E7.5. $n=5$ mice. The value is the mean. Error bars denote the s.d. $* * P=0.01$, Student's $t$-test. d, Uterus explanted at E7.5 after a physiological development (blastocyst-induced), the transfer of blastoids only in the left horn (blastoid-induced, also see the same uterus in Fig. 2h), and the instillation of oil (oil-induced). e, Histological sections of deciduae produced by blastocysts, blastoids and oil instillation, and stained using an anti-ALDH3A1 antibody. Scale bar, $100 \mu \mathrm{m}$. This experiment is a representation of three similar experiments. 
a

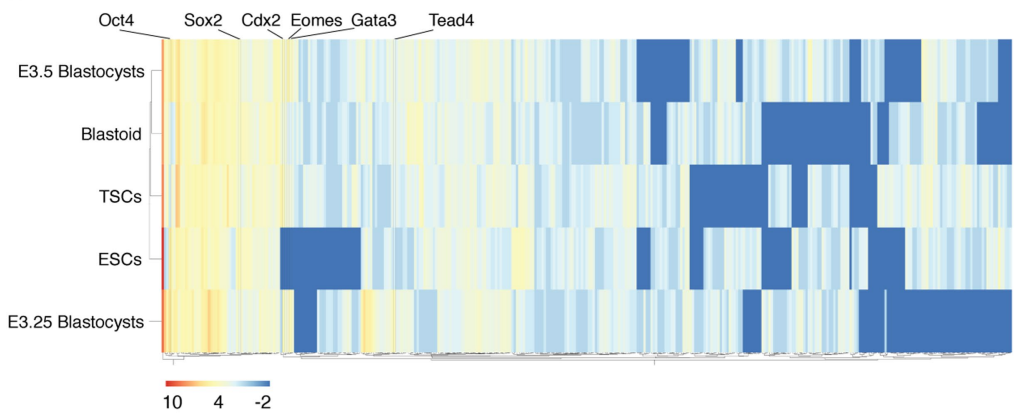

b

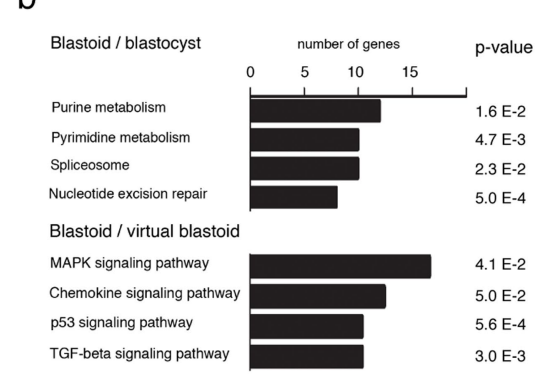

d
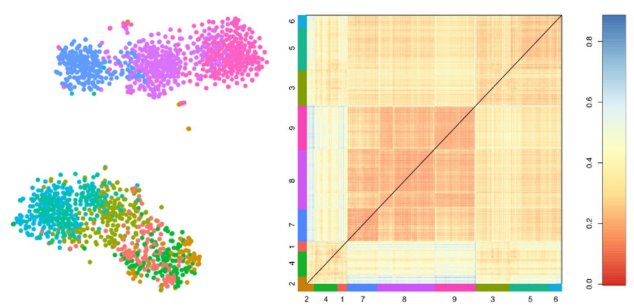

Trophoblasts in blastoids (3D)

- ESCs in 2i medium (2D)

- Embryoid bodies (3D)

- Embryonic cells in blastoids (3D)

- TSCs in TX medium (2D) Trophospheres (3D)

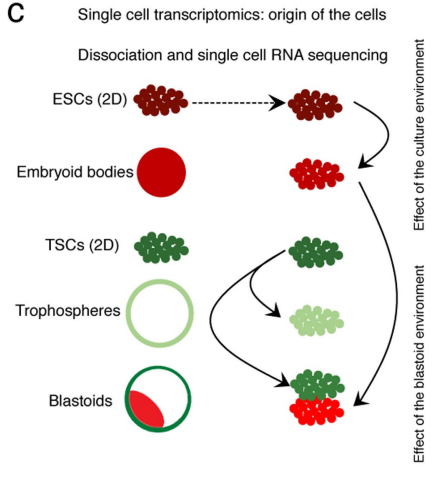

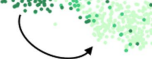

Culture environment

Transcriptome-wide clustering

astoid environment Culture environment

ra
Trophoblasts in blastoids (3D) e

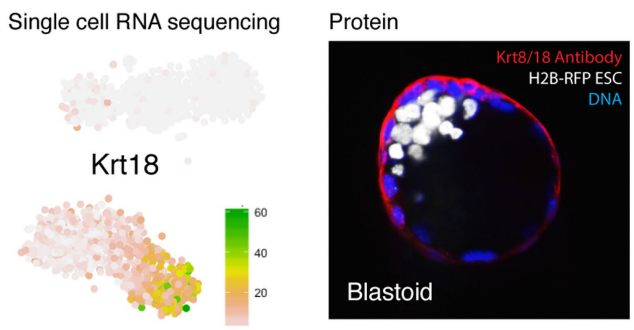

Single cell RNA sequencing

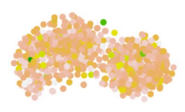

Oct4

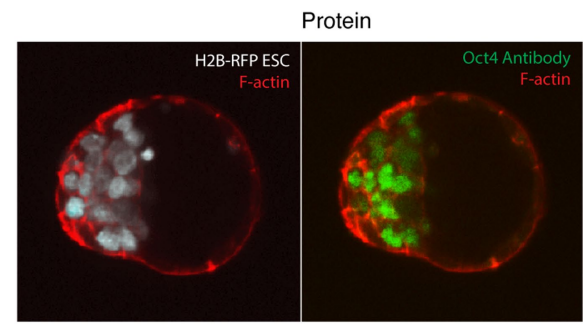

f tSNE maps of trophoblasts markers
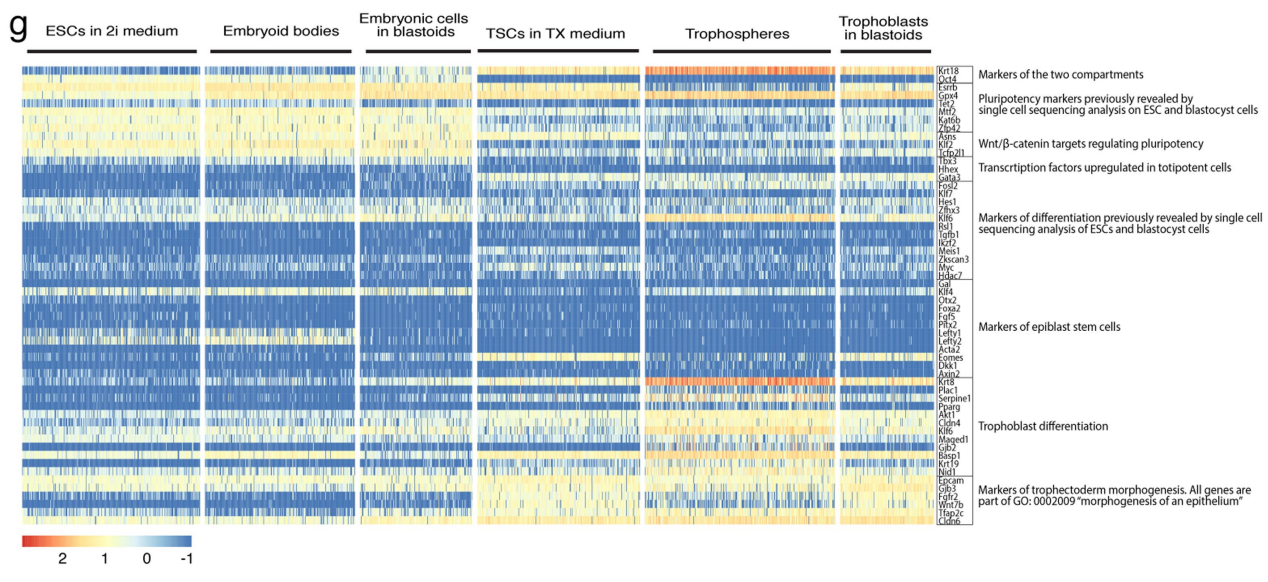

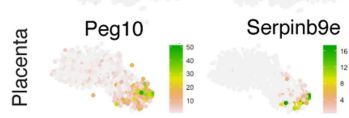

$\begin{array}{llll}2 & 1 & 0 & -1\end{array}$

Extended Data Fig. 6 | See next page for caption. 
Extended Data Fig. 6 | Bulk and single-cell RNA sequencing of blastoids and blastocysts. a, b, Bulk RNA sequencing. a, Transcription factor expression distance map. Differentially expressed transcription factors between the ES cells, TS cells, blastoids, virtual blastoids (see Methods), E3.25 and E3.5 blastocysts $(P<0.05$, DESeq negative binomial distribution) were used to generate a non-supervised distance map of transcription factors selected according to the Riken transcription factor database. The scale is $\log _{2}$. $\mathbf{b}$, Gene ontology (GO) and KEGG pathways. Genes differentially regulated $(P<0.05$, DESeq negative binomial distribution) were analysed using DAVID ${ }^{38}$ and corresponding GO and KEGG pathways are presented. The full lists of genes related to the depicted GO terms are in Supplementary Table 1 sheet 1. c-e, Single-cell sequencing. c, Schematic depicting the origin of the single cells. $t$-SNE maps of single cells from ES cells, TS cells, blastoids, trophospheres and embryoid bodies. The colours represent the origin of cells assessed by FACS sorting indexes (Supplementary Table 1 sheet 8 ). d, Clusters of similar cells, as generated by the RACE-ID protocol ${ }^{36}$. The heat map on the right is the distance map of single cells. The clusters from the $t$ -
SNE map and from the heat map are identified using the same colour code. Cells were processed as described in the Methods. e, The Krt18 and Oct4 genes are markers of the blastocyst trophectoderm and ICM compartments, respectively ${ }^{41}$, which we confirmed are also valid to mark the compartments of blastoids using immunohistochemistry (KRT8/18 and OCT4) and $\mathrm{H} 2 \mathrm{~B}-\mathrm{RFP}^{+} \mathrm{ES}$ cells. This image is representative of three independent blastoid experiments. f, $t$-SNE map representation of key genes for the trophectoderm, trophoblast differentiation and placental cell types. g, Heat map showing expression of genes of interest: markers of the trophectoderm and ICM compartments by Krt18 and Oct4, as identified in e; markers of pluripotency and differentiation, previously identified in ES cells and blastocyst cells via single-cell sequencing ${ }^{42}$; genes previously identified as markers of $\mathrm{WNT} / \beta$-catenin targets regulating a naive state of pluripotency ${ }^{43}$; transcription factors upregulated in totipotent cells ${ }^{44}$; genes previously identified as differentiation markers in ES cells via singlecell sequencing ${ }^{42}$; genes previously identified as markers differentiating ES cells from epiblast stem cells ${ }^{30}$; markers of trophoblast differentiation; and markers of trophectoderm morphogenesis. The scale is $\log _{10}$. 
a

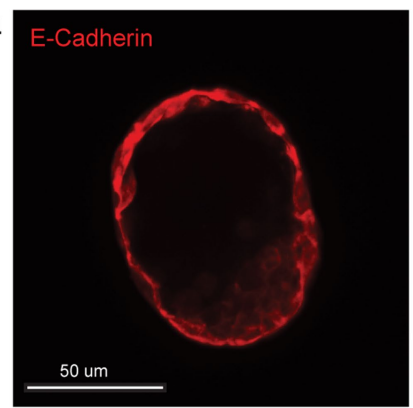

b

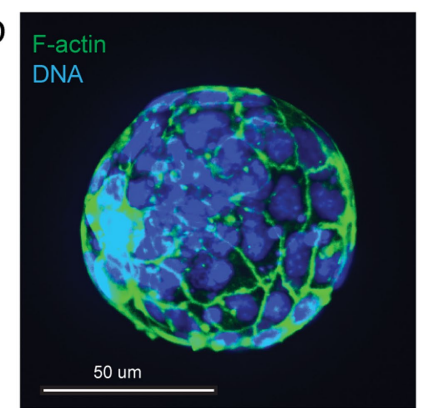

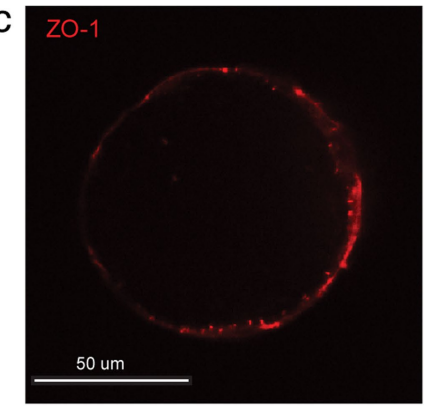

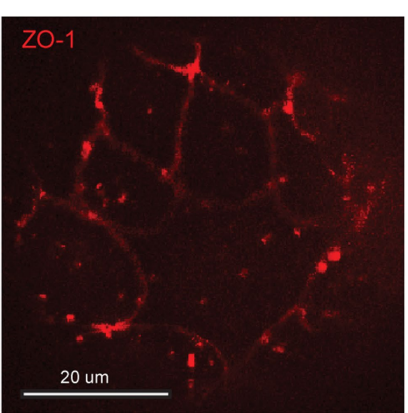

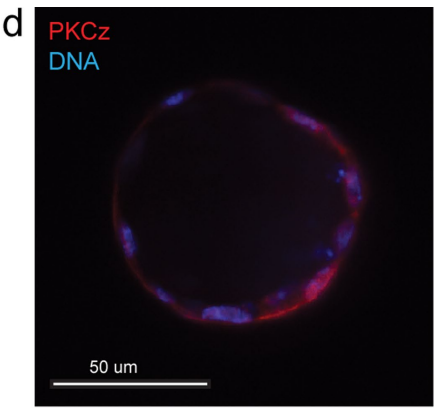

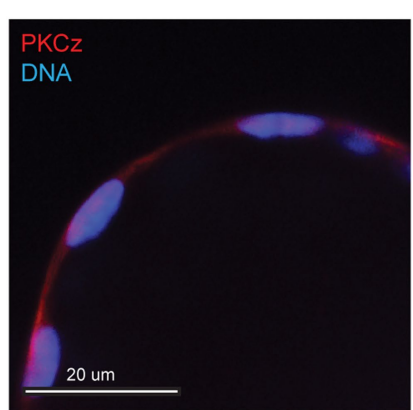

Extended Data Fig. 7 | Immunohistochemistry of epithelial markers within blastoids. a, Cross-section of a blastoid stained with an antibody against E-cadherin. Maximum projection of 5 images taken with a $1-\mu \mathrm{m}$ step. $\mathbf{b}$, Phalloidin staining of the cytoskeletal molecule F-actin and Hoechst staining of DNA show the localization of actin at cell-cell junctions. Maximum projection of 40 images taken with a 1- $\mu \mathrm{m}$ step. c) Antibody against the tight junction molecule ZO-1. Section of $0.5 \mu \mathrm{m}$ (top). Maximum projection of 4 images taken with a $0.5-\mu \mathrm{m}$ step (bottom). d, Antibody against the apical molecule $\mathrm{PKCz}$ and Hoechst staining of DNA. Section of $1 \mu \mathrm{m}$ (top); close up (bottom). All pictures were taken with a PerkinElmer Ultraview VoX spinning disk microscope combined with a Leica SP8. Images are representative of three experiments. 
a

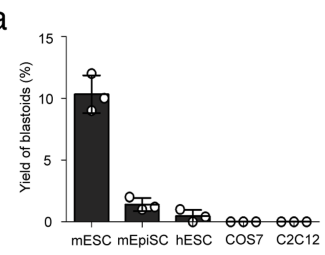

hES cells

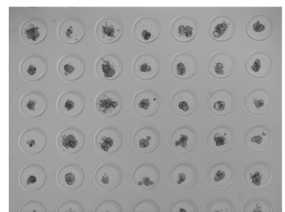

mES cells

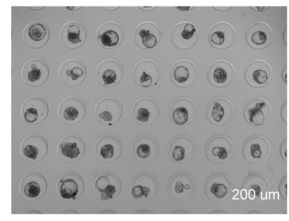

C2C12 cells

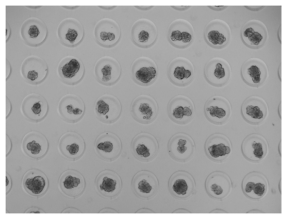

mEpis cells

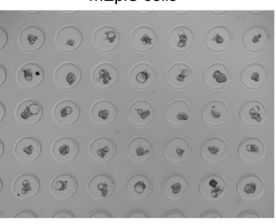

cos7 cells

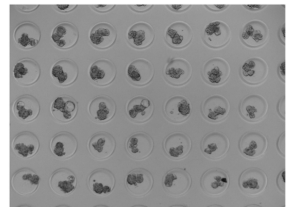

b

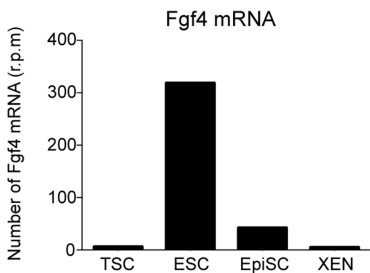

C Inventory of signaling pathways induced in trophoblasts by the embryonic cells. KEGG pathway analysis of trophoblasts from blastoids versus trophospheres

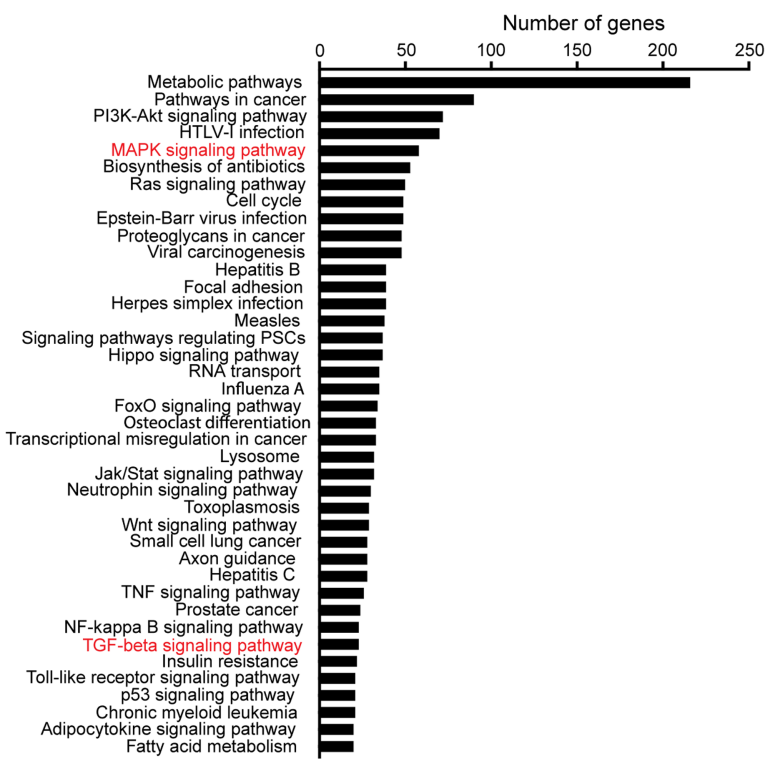

d Genes from selected KEGG pathways Trophoblasts from blastoids versus trophospheres

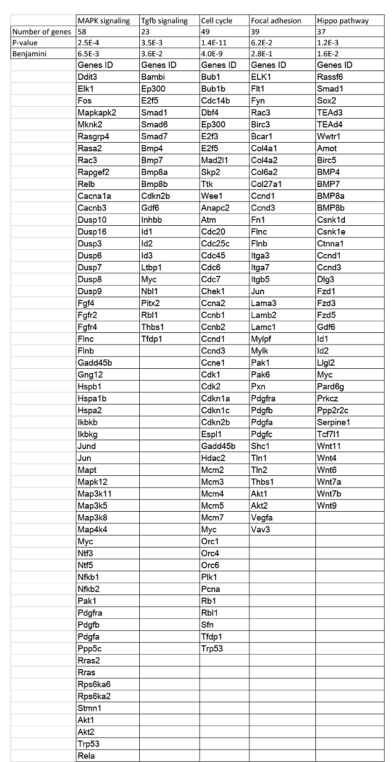

e
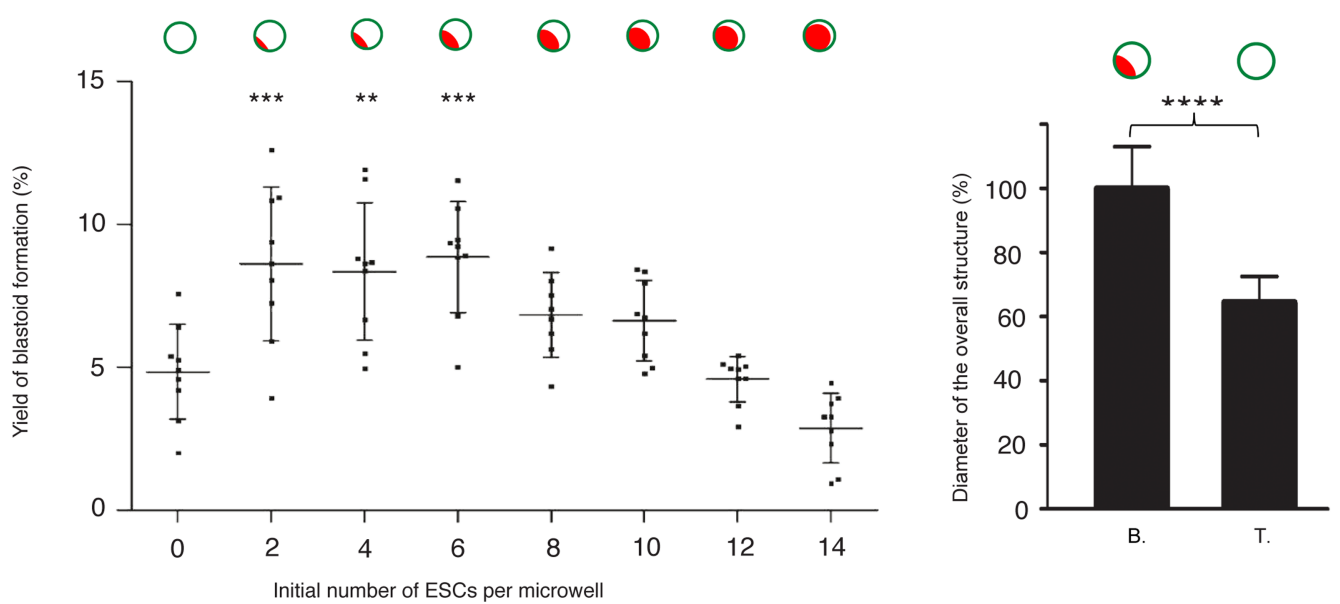

Extended Data Fig. 8 | See next page for caption. 
Extended Data Fig. 8 Assays of embryonic and trophectoderm

compartments interactions. a, Specificity of the ES cell inductions. Yield of formation and representative images of arrays of blastoids resulting from the association of TS cells with ES cells, EpiSCs, human ES cells, COS7 or C2C12 cells. $n=3$ independent microwell arrays. Centre depicts median values. Error bar denote s.d. b, Number of Fgf4 mRNA transcripts measured by RNA sequencing in TS cells, ES cells, EpiSCs and XEN cells (extra-embryonic endoderm cell lines). c, Inventory of signalling pathways induced in trophoblasts by the embryonic cells: KEGG pathways differentiating the trophoblasts from blastoids and trophospheres. The list is exhaustive and generated using the list of statistically differentiated genes $(P<0.05$, DESeq negative binomial distribution) with the highest fold changes (the 1,500 most highly upregulated and most highly downregulated genes). See the SORT-seq method described previously ${ }^{33}$. d, Selected KEGG pathways and genes related to the MAPK signalling pathway, TGF $\beta$ signalling pathway, cell cycle, focal adhesion and hippo pathway. e, Trophectoderm morphogenesis. Blastoids were assessed based on our definition of cavitated trophoblast structures comprising ES cells, with a circularity greater than $0.9\left(\right.$ circularity $=4 \pi\left(\right.$ area/perimeter $\left.{ }^{2}\right)$ ), and a diameter between 70 and $110 \mu \mathrm{m}$ (see Methods). Yield of blastoids (percentage per microwell array) as a function of the initial mean number of ES cells per microwell array. Horizontal bars denote mean yield. Error bars indicate s.d. $* * P=0.01, * * * P=0.001$, one-way analysis of variance (one-way ANOVA) and Tukey's test. $n=8$ independent microwell arrays. f, The diameter of blastoids and trophospheres measured at $65 \mathrm{~h} . n=50$. $* * * * P=0.0001$, two-sided Student's $t$-test. Centre values depict median. Error bar denote s.d. Representative images are shown in Fig. 4a. 
Single molecule FISH of TGFb pathway components
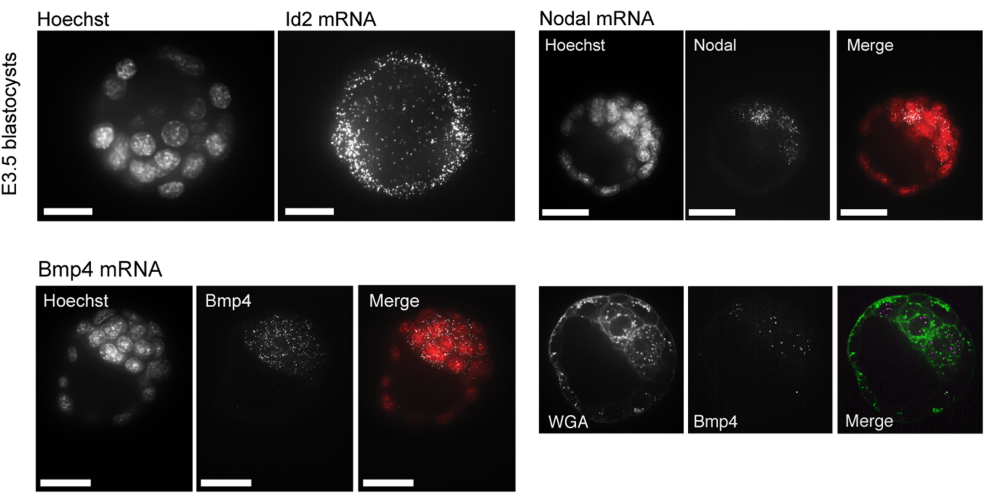

b

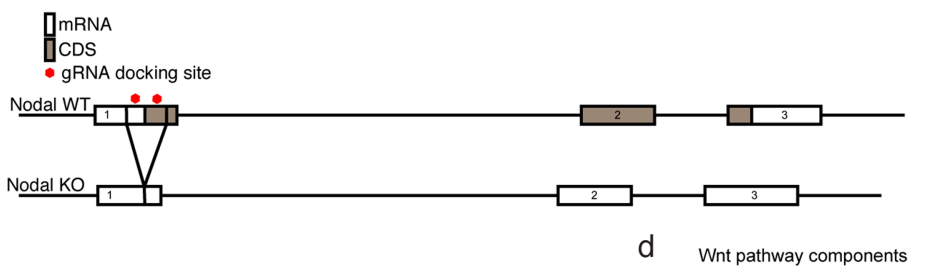

C Differentially regulated genes upon Nodal, Bmp4 or Nodal + Bmp4 stimulation Differentially regulated genes $(p<0.05)$
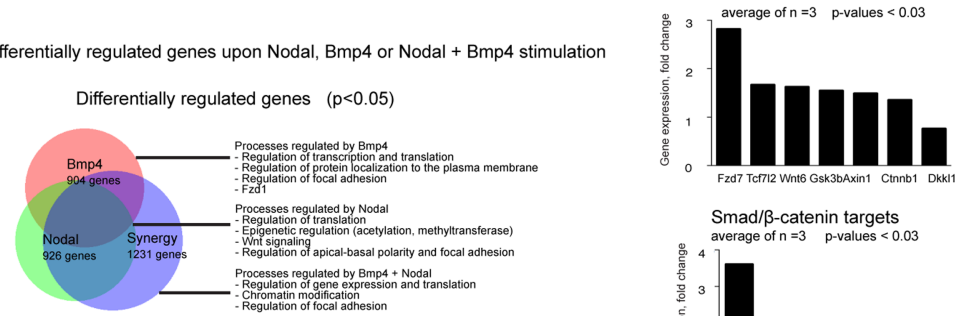
Smad/ $\beta$-catenin targets
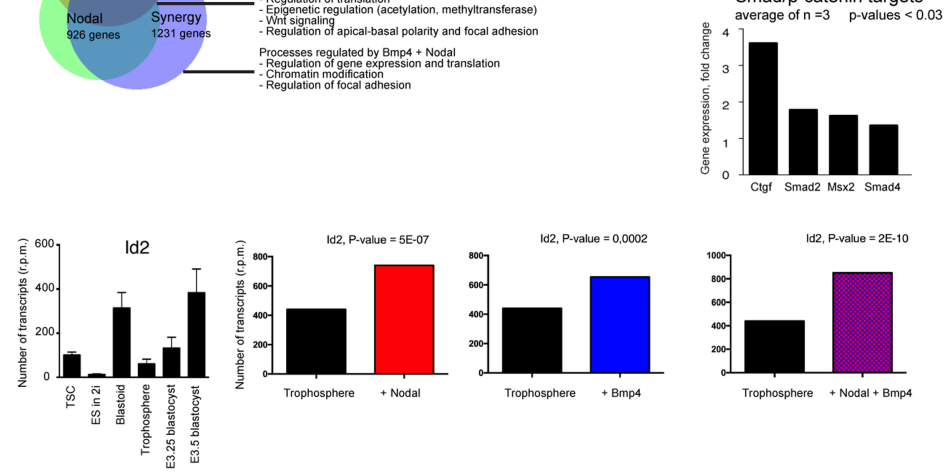

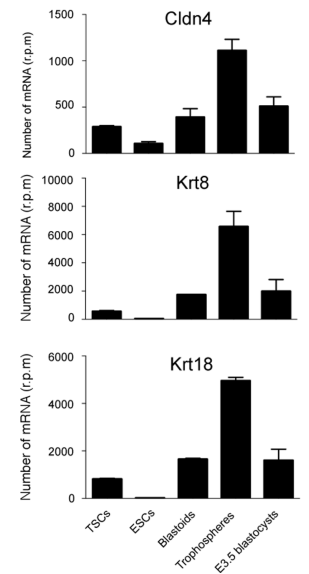

g

g Trophectoderm cavitation

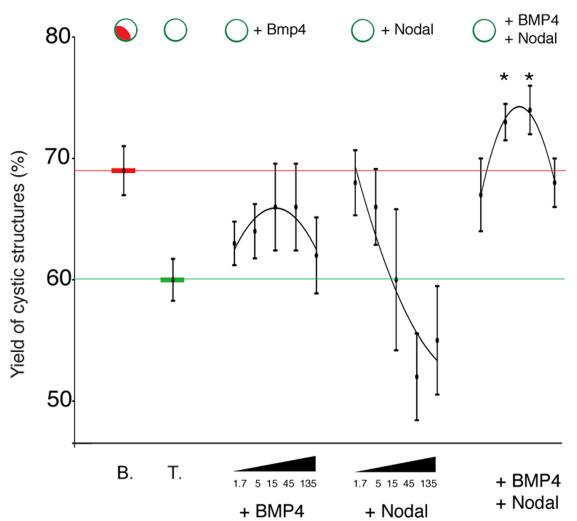

Extended Data Fig. 9 | See next page for caption. 
Extended Data Fig. 9 | Markers, transcriptional and morphogenetic functions of TGF $\beta$ signalling. a, Single-molecule FISH for Id2, Bmp 4 and Nodal genes of the TGF $\beta$ pathway, in an E3.5 blastocyst counterstained with Hoechst. Images are representative of five independent blastocysts. Scales bars are $30 \mu \mathrm{m}$ for Id 2 and $50 \mu \mathrm{m}$ for Nodal and Bmp $4 \mathbf{b}$, CRISPR strategy for the generation of Nodal deletion in ES cells. c, Venn diagram of all genes regulated after exposure to BMP4, Nodal or both (synergy). RNA sequencing showed that BMP4 and Nodal regulated a similar number of genes (BMP4: 904 genes, Nodal: 926 genes, genes with $P<0.05$ (DESeq negative binomial distribution), of which $30 \%$ overlapped (413 genes). The GO analysis is shown for each group. See also Supplementary Table 2 sheets 1-4. d, RNA-sequencing analysis of the WNT-related genes in trophospheres stimulated with activators of the TGF $\beta$ signalling pathway. All genes are significantly regulated $(P=0.03$, DESeq negative binomial distribution). This included the ligand Wnt6 (1.6-fold, $P=0.006$, DESeq negative binomial distribution), which is expressed primarily in the cells surrounding the blastocyst cavity ${ }^{10}$, the corresponding receptor $F z d 7$ (2.8fold, $P=0.002$, DESeq negative binomial distribution), the intracellular effector Tcf4 (also known as Tcf7l2; 1.7-fold, $P=0.001$, DESeq negative binomial distribution), the negative-feedback regulator Axin1 (1.5-fold, $P=0.005$, DESeq negative binomial distribution, top), and of the reported cooperative SMAD $/ \beta$-catenin targets $M s \times 2$ (1.6-fold, $P=0.00003$, DESeq negative binomial distribution $)^{45}$ and $\operatorname{Ctg} f$ (3.6-fold, $P=0.003$, DESeq negative binomial distribution $)^{46}$ (bottom). See also Supplementary Table 2 sheets 1-4. e, RNA-sequencing analysis of the $T g f b$-related gene Id2 in TS cells, ES cells, blastoids, trophospheres, blastocysts (left) and in trophospheres after stimulation with Nodal, BMP4 or both (see Methods) (right). $n=2$ independent biological samples. The centre depicts the mean. Error bars denote the s.d. f, Number of transcripts measured by RNA-sequencing analysis for markers of epithelial development $\mathrm{Cldn} 4$, $K r t 8$ and $K r t 18 . n=2$ independent biological samples. The centre depicts the mean. Error bars denote the s.d. g, Yield of cystic structures for a combination of ES and TS cells as compared to TS cells alone (trophospheres) and trophospheres stimulated with BMP4 and Nodal. Horizontal bars denote the mean yield. Error bars are s.d. $* P=0.02$, Student's $t$-test. $n=3$ independent microwell arrays (see Methods). 

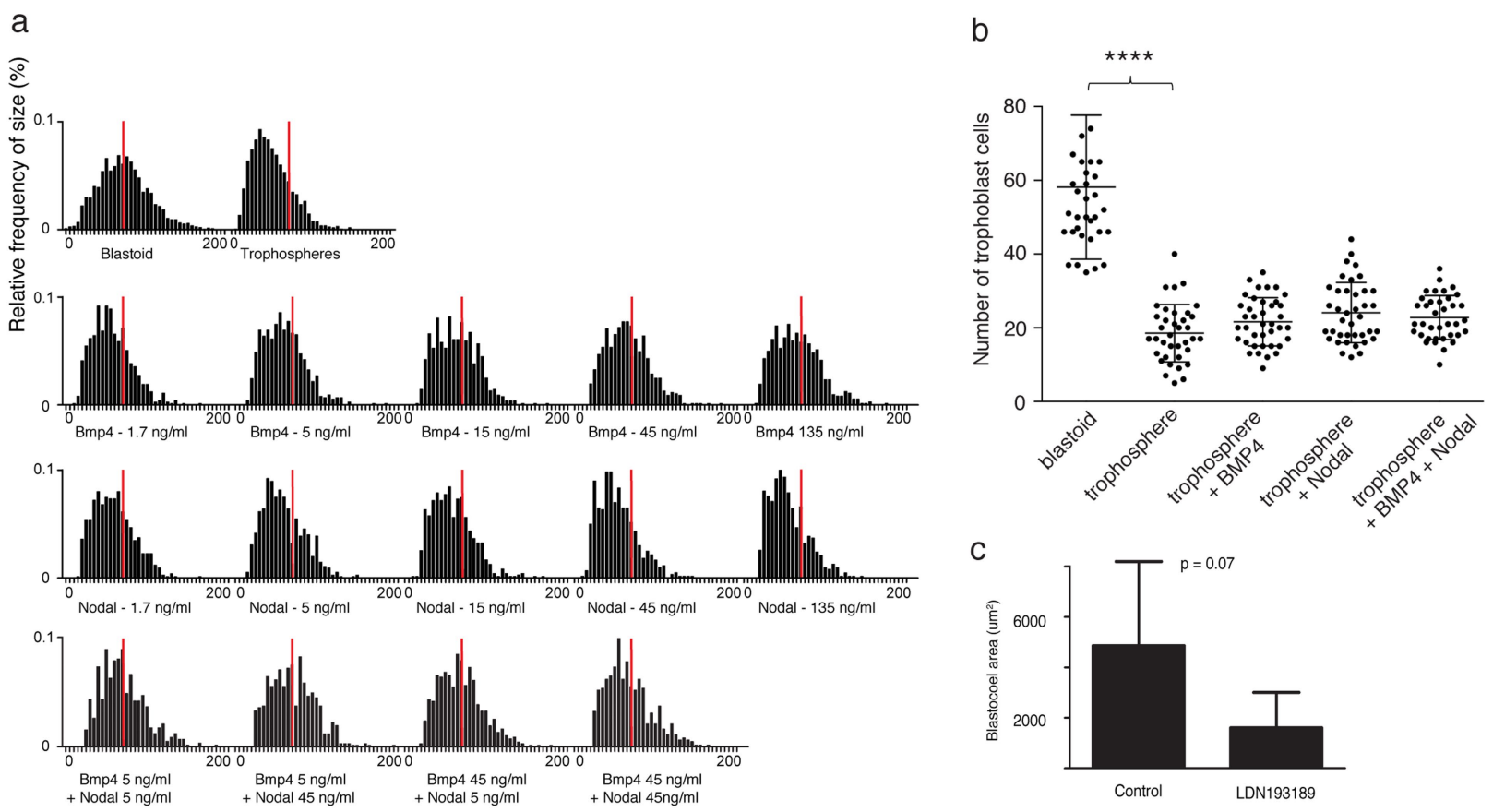

d Trophoblast stem cells Knock Out of KLF6
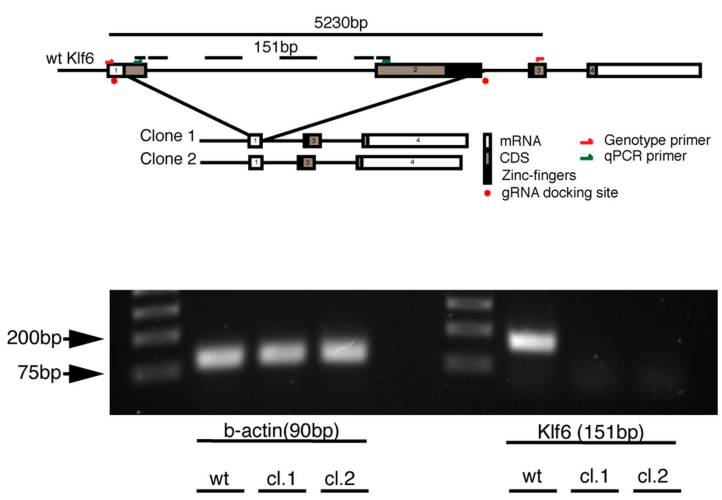

e

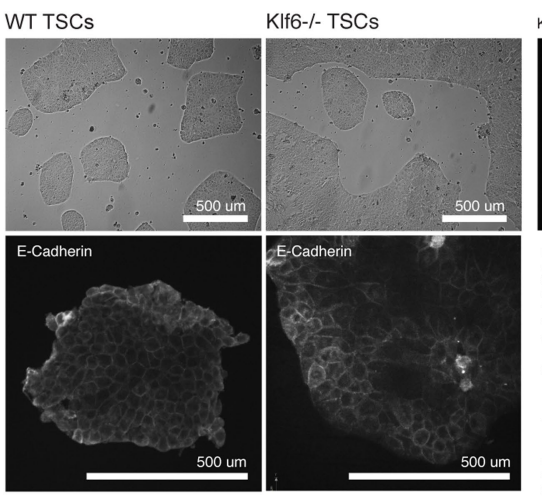

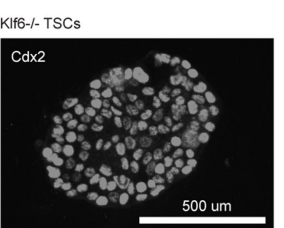

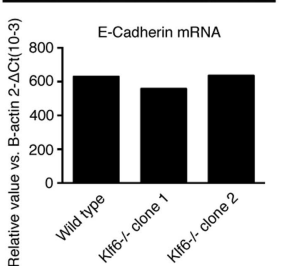

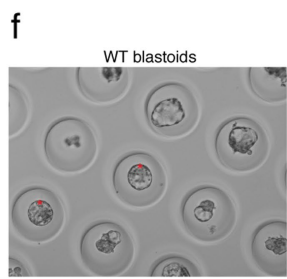

Klf6-/. blastoids

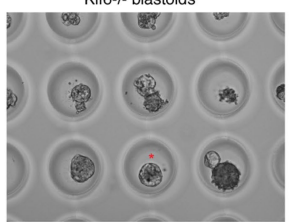

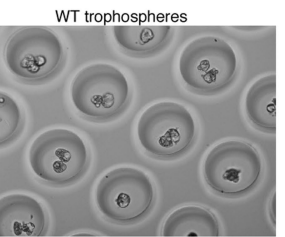

KIf6-I- trophospheres

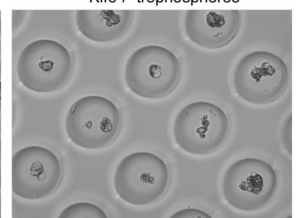

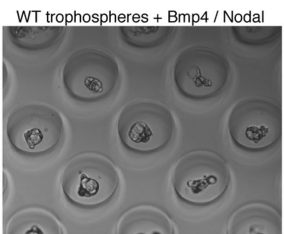

Klf6-I- trophospheres + Bmp4 / Nodal

\section{Klf6-I- trophospheres + Bmp4 / Nodal}

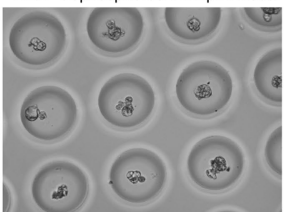

g

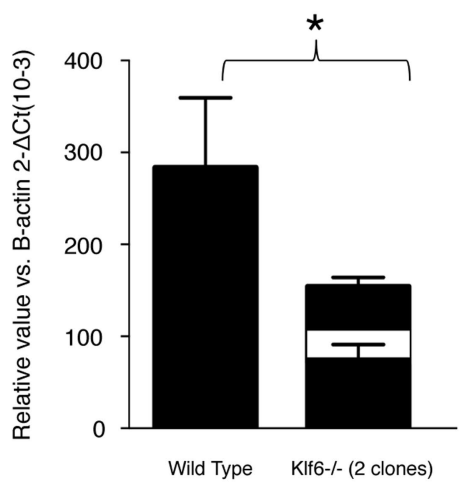

Extended Data Fig. 10 | See next page for caption. 
Extended Data Fig. 10 | Generating and assaying blastoids with Klf $^{-1-}$ TS cells. a, Frequency distribution of the diameter of blastoids, trophospheres and trophospheres exposed to BMP4 and Nodal $(\mu \mathrm{m})$. For all graphics, the red bar is the median as measured for blastoids. b, Number of trophoblasts within blastoids, trophospheres and trophospheres stimulated with activators of the TGF $\beta$ signalling pathway. $n=30$ independent blastoids or trophospheres. $P=0.0001$, one-way ANOVA. The same graph is shown in part in fig. $4 \mathrm{~b}$. c, Effect of smallmolecule inhibitors on blastocyst cavitation. Morula were flushed from the oviduct of E2.5 CBA $\times$ C57BL/6 mice and cultured in M16 medium. After the initiation of morula compaction, inhibitors or DMSO $(1: 1,000$, control) were added. LDN193189 $(0.25 \mu \mathrm{M})$ was used to inhibit ALK2 and ALK3 (SMAD pathway). Blastocysts were imaged $24 \mathrm{~h}$ after exposure. $n=10$ independent blastocysts. $P=0.07$, two-sided Student's $t$-test. Error bars denote s.d. d, Targeting strategy of KLF6 in TS cells and PCR gel of the obtained clones. e, Bright-field image of wild-type and $\mathrm{Klf}^{-/-} \mathrm{TS}$ cells (top left). Immunostaining for CDX2 in $\mathrm{Klf6}^{-1-}$ TS cells (top right). E-cadherin immunostaining (bottom left) and quantitative PCR with reverse transcription (qRT-qPCR) (bottom right) of wild-type and $\mathrm{Klf}^{-1-}$ TS cells. f, Representative pictures of blastoids and trophospheres, and trophospheres stimulated with $45 \mathrm{ng} \mathrm{ml}^{-1} \mathrm{BMP} 4$ and $5 \mathrm{ng} \mathrm{ml}^{-1}$ Nodal. Red asterisks denote blastoids, which comply to our definition of cavitated trophoblast structures comprising ES cells, with a circularity greater than $0.9\left(\right.$ circularity $=4 \pi\left(\right.$ area/perimeter $\left.\left.{ }^{2}\right)\right)$, and a diameter between 70 and $110 \mu \mathrm{m}$ (see Methods). Comparable results were obtained in three repeated experiments. g, qRT-PCR for $\mathrm{Krt} 8$ in structures formed by combining ES cells and wild-type or $\mathrm{Klf6}^{-1-}$ TS cells. All structures (blastoids and nonblastoids) were collected from the microwell arrays and tested. Horizontal bars indicate mean expression. Error bars denote s.d. $n=3$ pools from independent microwell arrays. $* P=0.04$, two-sided Student's $t$-test. 


\section{Life Sciences Reporting Summary}

Nature Research wishes to improve the reproducibility of the work that we publish. This form is intended for publication with all accepted life science papers and provides structure for consistency and transparency in reporting. Every life science submission will use this form; some list items might not apply to an individual manuscript, but all fields must be completed for clarity.

For further information on the points included in this form, see Reporting Life Sciences Research. For further information on Nature Research policies, including our data availability policy, see Authors \& Referees and the Editorial Policy Checklist.

Please do not complete any field with "not applicable" or n/a. Refer to the help text for what text to use if an item is not relevant to your study. For final submission: please carefully check your responses for accuracy; you will not be able to make changes later.

\section{- Experimental design}

1. Sample size

Describe how sample size was determined.

For each experiment, the sample size is determined based on an interval of confidence equal or above $95 \%$ as described in the methods and in the text, and on the sampling error, which is estimated based on the standard deviations during pilot studies.

\section{Data exclusions}

Describe any data exclusions.

There was no data exclusion.

3. Replication

Describe the measures taken to verify the reproducibility of the experimental findings.

4. Randomization

Describe how samples/organisms/participants were allocated into experimental groups.

All attempts at replication were successful.

\section{Blinding}

Describe whether the investigators were blinded to group allocation during data collection and/or analysis.

Samples were allocated to groups prior to treatments which prevented any bias in the interpretation of data.

Note: all in vivo studies must report how sample size was determined and whether blinding and randomization were used.

6. Statistical parameters

For all figures and tables that use statistical methods, confirm that the following items are present in relevant figure legends (or in the Methods section if additional space is needed).

$\mathrm{n} / \mathrm{a}$ Confirmed

$\bigotimes$ The exact sample size $(n)$ for each experimental group/condition, given as a discrete number and unit of measurement (animals, litters, cultures, etc.)

A description of how samples were collected, noting whether measurements were taken from distinct samples or whether the same sample was measured repeatedly

$\bigotimes$ A statement indicating how many times each experiment was replicated

$\varnothing$ The statistical test(s) used and whether they are one- or two-sided

Only common tests should be described solely by name; describe more complex techniques in the Methods section.

Х $\square$ A description of any assumptions or corrections, such as an adjustment for multiple comparisons

Test values indicating whether an effect is present

Provide confidence intervals or give results of significance tests (e.g. P values) as exact values whenever appropriate and with effect sizes noted.

A clear description of statistics including central tendency (e.g. median, mean) and variation (e.g. standard deviation, interquartile range)

Clearly defined error bars in all relevant figure captions (with explicit mention of central tendency and variation) 
Policy information about availability of computer code

\section{Software}

Describe the software used to analyze the data in this study.

For manuscripts utilizing custom algorithms or software that are central to the paper but not yet described in the published literature, software must be made available to editors and reviewers upon request. We strongly encourage code deposition in a community repository (e.g. GitHub). Nature Methods guidance for providing algorithms and software for publication provides further information on this topic.

\section{- Materials and reagents}

Policy information about availability of materials

\section{Materials availability}

Indicate whether there are restrictions on availability of unique materials or if these materials are only available for distribution by a third party.

\section{Antibodies}

Describe the antibodies used and how they were validated for use in the system under study (i.e. assay and species).
No unique materials were used.

Immunofluorescence was performed as described by the laboratory of Janet Rossant (http://www.sickkids.ca/research/rossant/protocols/

AntibodyStainingEarlyEmbryos.pdf). Antibodies were used against Cdx2 (MU392AUC; 1/400 dilution), Nanog (Abcam ab84447; dilution 1/200), Oct4 (Santa Cruz 5279; $1 / 200$ dilution), GATA-6 (R\&D Systems AF1700; 1/200), PDGFRa (R\&D Systems AF1062; $1 / 150$ dilution), Elf5 (Santa Cruz sc-9645; 1/250 dilution), Mash2 (also known as Ascl2, Genetex GTX60272; 1/250 dilution), TEAD4 (Abcam ab58310; 1/400 dilution) and Proliferin (E10, Santa Cruz sc-271891; 1/250 dilution), Tpbpa (Abcam ab104401; 1/250 dilution), Placenta lactogen (P17, Santa Crux, sc-34713; 1/200 dilution), Hand1 (Abcam ab115256; 1/250 dilution), and Ecadherin clone DECMA-1 (Sigma U3254; 1/500 dilution). All images were taken using a PerkinElmer Ultraview VoX spinning disk microscope combined with a Leica SP8. All antibodies were validated by using blastocysts and embryos. All secondary antibodies are Alexa fluor (Invitrogen). 
10. Eukaryotic cell lines

a. State the source of each eukaryotic cell line used.
Culture of ESCs.

Experiments were done using the following cell lines: V6.5, H2B-RFP V6.5 subclone, PDGFRa-H2B-GFP, Sox17-GFP and IB10. The V6.5 cell line was derived from

C57BL/ $6 \times 129 / S v$ background and obtained from the laboratory of Rudolf Jaenisch. The IB10 cell line was a subclone of the E14 cell line (129/Ola) and obtained from the laboratory of Hans Clevers. The PDGFRa-H2B-GFP cell line was derived from an ICR background and obtained from the laboratory of Anna-Katerina Hadjantonakis. The Sox17-GFP cell line was derived from unknown background and obtained from the laboratory of Sean Morrison. All cells were cultured on gelatin-coated plates in B27N2 medium complemented with leukemia inhibitory factor (LIF, $10 \mathrm{ng} / \mathrm{ml}$ ), PD0325901 (1 uM, AxonMed 1408) and CHIR99023 (3 uM, AxonMed 1386) as developed by Ying et. al.17. Cells were routinely passaged every two days for 15 days before being used for blastoid formation.

Culture of TSCs.

Experiments were done using the F4, F1 and Cdx2-eGFP cell lines. The TSC lines F4 $(I C R \times I C R)$ were obtained from the laboratory of Janet Rossant. The F1 (CBA $\times$ C57BI6) and Cdx2-eGFP TSC lines were derived by Nicolas Rivron according to the methods described by Satoshi Tanaka et. al.9. Cdx2-eGFP TSC lines were derived from a mouse reporter line in which eGFP is fused to the endogenous locus of $\mathrm{Cdx2}$, as described by McDole et. al.23. Cells were then cultured on Matrigel in phenol red-free TX medium, a serum-free medium developed by Kubaczka et. al.18. TX medium contains D-MEM/F12 (phenol red-free, with L-glutamin), LAscorbicAcid-2-Phosphat (64 $\mu \mathrm{g} / \mathrm{ml})$, sodium-selenite $(14 \mathrm{ng} / \mathrm{ml})$, insulin $(19.4 \mu \mathrm{g} /$ $\mathrm{ml})$, sodium bicarbonate $(543 \mu \mathrm{g} / \mathrm{ml})$, holo-transferin $(10.7 \mu \mathrm{g} / \mathrm{ml})$, penicillin streptomycin, fibroblast growth factor $4(\mathrm{Fgf} 4,25 \mathrm{ng} / \mathrm{ml})$, transforming growth factor 1 (Tgfb1, $2 \mathrm{ng} / \mathrm{ml}$ ) and heparin $(1 \mu \mathrm{g} / \mathrm{ml})$ in. Alternatively, and when mentioned, TSC cells were cultured with serum condition (TS medium) as described by Tanaka et. al.9. Cells were routinely passaged every $2-4$ days for 10 days before being used for blastoid formation.

Culture of other cell types.

mEpiSCs were cultured serum-free as previously described52. hESCs were cultured in E8 medium. C2C12 and COS7 cells were culture in DMEM (Gibco, phenol redfree with L-glutamin), supplemented with 10\% Fetal Bovine Serum (Sigma-Aldrich). The V6.5 cell line was derived from C57BL/6 $\times 129 /$ Sv background and obtained from the laboratory of Rudolf Jaenisch. The IB10 cell line was a subclone of the E14 cell line (129/Ola) and obtained from the laboratory of Hans Clevers. The PDGFRa-H2B-GFP cell line was derived from an ICR background and obtained from the laboratory of Anna-Katerina Hadjantonakis. The Sox17GFP cell line was derived from unknown background and obtained from the laboratory of Sean Morrison. The TSC lines F4 (ICR $\times$ ICR) were obtained from the laboratory of Janet Rossant. The F1 (CBA $\times$ C57BI6) and CDX2-eGFP TSC lines were derived by Nicolas Rivron according to the methods described by Satoshi Tanaka et. al.. CDX2-eGFP TSC lines were derived from a mouse reporter line in which eGFP is fused to the endogenous locus of CDX2, as described by McDole et. al.

Chimera contribution upon injection into a E3.5 blastocyst.

Cells were routinely tested for mycoplasma contamination.

No commonly misidentified cell lines were used.

d. If any of the cell lines used are listed in the database of commonly misidentified cell lines maintained by ICLAC, provide a scientific rationale for their use.

\section{- Animals and human research participants}

Policy information about studies involving animals; when reporting animal research, follow the ARRIVE guidelines

\section{Description of research animals}

Provide all relevant details on animals and/or animal-derived materials used in the study.
ESCs or TSCs (12-15 cells) were injected into E3.5 blastocysts from C57BI6 mice. The injected blastocysts were transferred into the uterus of CBA $\times$ C57BI6 pseudopregnant females. Embryos were explanted from the uterus and dissected from the deciduae at E6.5.

The blastoids were directly transfered into the uterus of CBA $\times$ C57BI6 pseudopregnant females (6-9 weeks old).

Policy information about studies involving human research participants

\section{Description of human research participants}

Describe the covariate-relevant population characteristics of the human research participants.
Provide all relevant information on human research participants, such as age, gender, genotypic information, past and current diagnosis and treatment categories, etc. OR state that the study did not involve human research participants. 